\title{
O političkim aspektima proglašenja epidemije u okolici Velehrada u Moravskoj uoči proslave tisućite obljetnice smrti sv. Metoda 1885. godine
}

U radu su istražene okolnosti proglašenja epidemije u okolici Velehrada u Moravskoj uoči proslave tisućite obljetnice smrti sv. Metoda u Velehradu 5. srpnja 1885. kao ranoga primjera zloporabe medicine u političke svrhe. Kao osnova za istraživanje poslužila je mjera ograničenja kretanja, donijeta sporazumnom odlukom vlada Austro-Ugarske Monarhije i Ruskoga Carstva, kojom je onemogućen organizirani odlazak hodočasnika iz drugih dijelova Austro-Ugarske Monarhije i Ruskoga Carstva u Velehrad, premda se spomenuta epidemija realno uopće nije dogodila. Svrha zloporabe javnozdravstvenih mjera i zabrane kretanja bila je isključivo političke naravi, onemogućiti masovno slavensko vjersko okupljanje, rimokatolika i grkokatolika/unijata iz Austro-Ugarske Monarhije te grkokatolika i pravoslavaca iz Ruskoga Carstva. Velehradsku proslavu austrougarske vlasti shvaćale su isključivo kao opasno sredstvo panslavenske propagande i s njom povezane ugroze slavenskih zemalja Austro-Ugarske Monarhije od strane Ruskoga Carstva, napose u kontekstu afirmacije uporabe starocrkvenoslavenske liturgije kod katoličkih Slavena, a ruske vlasti kao sredstvo katoličkoga prozelitizma i „unijaćenja” te prijetnju za svoje vanjskopolitičke ambicije širenja utjecaja $\mathrm{Ru}$ skoga Carstva prema Zapadu, napose na Balkan, te za njegov prodor na topla mora. U prilog tezi da se pri proglašenju epidemije u okolici Velehrada 1885. radilo o jednom od ranih primjera zloporabe medicine u političke svrhe ističe se da te godine službene javnozdravstvene institucije nisu registrirale nikakvu epidemiju u Moravskoj unatoč vrlo dinamičnom razvoju mikrobiologije u tom razdoblju te sustavnom praćenju pojava različitih infektivnih bolesti i redovitom objavljivanju podataka o njima u medicin-

Zoran Grijak, Hrvatski institut za povijest, Opatička 10, 10000 Zagreb, Republika Hrvatska, E-mail adresa: zgrijak@isp.hr

** Ovaj rad nastao je u sklopu provedbe internoga znanstveno-istraživačkog projekta Hrvatskoga instituta za povijest Fenomen dubrovačkih Srba katolika u svjetlu korespondencije njegovih istaknutih predstavnika. 
skim publikacijama, što je sasvim isključivalo mogućnost da bilo koja epidemija s iole znatnijim smrtnim ishodom, da se zaista dogodila, ne bi bila medicinski registrirana. Događaji u vezi sa sprječavanjem Velehradske proslave 1885. u radu se napose analiziraju na temelju korespondencije biskupa Josipa Jurja Strossmayera s Lujom i Kostom Vojnovićem $s$ jedne te Franjom Račkim s druge strane. Na osnovi analize tadašnjih bečkih tiskovina Neue Freie Presse i Wiener Allgemeine Zeitung može se uočiti da su se od sredine lipnja u njima počele javljati vijesti o pojavi različitih infektivnih bolesti (šarlah, trbušni tifus, difterija, vodene kozice, ospice i dr.) u okolici Velehrada, koje se, bez bilo kakvih vjerodostojnih dokaza o stvarnoj pojavi tih bolesti, dovodilo u vezu s hodočasnicima koji su još od travnja 1885., u povodu tisućite godišnjice Metodove smrti 6. travnja, počeli pristizati u Moravsku. Cilj je bio, kako je napomenuto, omesti organizirani dolazak hodočasnika izvan Moravske, iz drugih dijelova Austro-Ugarske Monarhije i Ruskoga Carstva na glavnu proslavu u Velehradu 5. srpnja 1885., u čemu je postignut potpun uspjeh. Zloporabu političkih vlasti lažnim proglašenjem epidemije razotkrilo je Moravsko zdravstveno vijeće, koje je u svojem očitovanju od 3. srpnja 1885. ustvrdilo da nisu utvrđeni medicinski razlozi koji bi nalagali uvođenje epidemioloških mjera koje su po nalogu političkih vlasti aktualno provođene. Pritom treba upozoriti na to da je po učestalosti i intenzitetu te pojavljivanju i proširenosti epidemija/pandemija u Europi, ali i znatno šire, na globalnoj razini, u 19. stoljeću posebna prijetnja bila kolera, čiji se peti pandemijski val odvijao upravo u vrijeme Velehradske proslave 1885. Trajao je od 1881. do 1896. i s tim u vezi austrougarske su vlasti vrlo odgovorno provodile mjere epidemiološke zaštite da se epidemija, koja je napose zahvatila Španjolsku, ne bi proširila na njezin prostor. Zloporaba medicine od političkih autoriteta proglašenjem lažne epidemije, odnosno više različitih opasnih infektivnih bolesti u okolici Velehrada 1885., uzima se, s obzirom na to da se zasigurno radi o jednom od ranih primjera takve zloporabe uopće, kao osnova za utvrđivanje načelne legitimnosti propitivanja javnozdravstvenih odluka i mjera koje donose medicinski, a napose politički autoriteti u svim javnozdravstvenim prijetnjama u kojima se ozbiljnije ograničavaju zakonska i ustavna prava građana, uključujući i one u vezi s aktualnom pandemijom bolesti Covid-19, tijekom koje su građanima na svjetskoj razini ukinuta ili znatno sužena neka od temeljnih ustavnih prava, među kojima osobito pravo na slobodno kretanje, što je inače bila osnovna restriktivna mjera i tijekom proglašenja epidemije u okolici Velehrada u Moravskoj 1885. godine.

Ključne riječi: Velehradska proslava 1885., sv. Ćiril i Metod, zloporaba epidemije u političke svrhe, Austro-Ugarska Monarhija, Rusko Carstvo, Trojedna Kraljevina, Josip Juraj Strossmayer, Lujo Vojnović, Kosto Vojnović, Franjo Rački

\section{Uvod}

$\mathrm{U}$ trenutku kad se svakodnevno suočavamo s različitim aspektima pandemije bolesti Covid-19, koja je već dulje od godinu dana akutni globalni javnozdravstveni problem, gotovo sve zemlje preusmjerile su goleme resurse u njezino suzbijanje, nastojeći ujedno očuvati gospodarstvo. Radi njezina sprječavanja uvedene su brojne epidemiološke mjere, popraćene, uz ostalo, suspenzijom ili ograniče- 
njem nekih od temeljnih ustavnih prava da bi se njezini nepovoljni ishodi sveli na najmanju moguću mjeru. Problem takvih mjera nije toliko bitno sadržan u samom činu njihova uvođenja, kad nadležne javnozdravstvene institucije utvrde visoku razinu epidemiološke prijetnje, koliko u osiguranju vladavine prava tijekom njihove provedbe. ${ }^{1}$ Dakle, kao iznimno relevantno postavilo se pitanje osiguranja načela vladavine prava i koncepta ustavne vladavine u situaciji kad su u bitnom smislu ograničena neka od temeljnih ustavnih prava građana. U Republici Hrvatskoj ta prava štite se člankom 14. Ustava, utemeljenom na međunarodnim konvencijama o zaštiti ljudskih prava Ujedinjenih naroda i drugim zakonodavnim aktima te na pravnoj stečevini Europske unije. ${ }^{2}$ Ograničenje tih ustavnih prava moguće je isključivo na temelju članka 16. Ustava Republike Hrvatske, kojim se predviđa da se slobode i prava mogu ograničiti samo da bi se zaštitila sloboda i prava drugih ljudi, pravni poredak, javni moral i zdravlje, te članka 17., kojim se predviđa ograničenje ljudskih sloboda i prava u slučaju neposredne ugroženosti neovisnosti i sigurnosti države te velikih prirodnih nepogoda. ${ }^{3} \mathrm{~S}$ obzirom na to da su sve mjere ograničenja ljudskih prava i sloboda u Hrvatskoj bile uvedene na temelju članka 16 . Ustava, a pojedini stručnjaci smatrali su da je za neke od njih bila potrebna i primjena članka 17., pitanje ograničenja ljudskih prava i sloboda u vrijeme pandemije Covida-19 postalo je predmet rasprava $u$ krugu eksperata za ustavno pravo. No, ovdje nije moguće time se detaljnije baviti, kako s obzirom na opseg članka i njegovu temu tako i uzimajući u obzir da temeljitija rasprava o tome spada u domenu kompetentnih stručnjaka iz područja ustavnoga prava. Za ovaj je prilog, s obzirom na temu kojoj je posvećen - zabranu kretanja kao epidemiološke mjere pri proglašavanju epidemije u okolici Velehra-

\footnotetext{
1 Polazišna teza za osiguranje vladavine prava jest visoko koegzistiranje načela vladavine prava i pravne države koja ta načela provodi u praksi. Pojam vladavina prava označava sustav političke vlasti utemeljen na poštovanju ustava, zakona i drugih propisa građana i samih nositelja državne vlasti. Svi zakoni i drugi propisi, kao i postupci nositelja vlasti, trebaju biti utemeljeni na zakonu, odnosno na zakonu utemeljenom propisu. To izražava ustavno načelo ustavnosti i zakonitosti. Zvonimir Lauc, „Načelo vladavine prava u teoriji i praksi”, Pravni vjesnik: časopis za pravne i društvene znanosti Pravnog fakulteta Sveučilišta Josipa Jurja Strossmayera u Osijeku 32 (2016), br. 3-4: 48.
}

2 Članak 14. Ustava Republike Hrvatske proklamira pravo svakoga u Republici Hrvatskoj na Ustavom zajamčena prava i slobode, neovisno o njegovoj rasi, boji kože, spolu, jeziku, vjeri, političkom ili drugom uvjerenju, nacionalnom ili socijalnom podrijetlu, imovini, rođenju, naobrazbi, društvenom položaju i drugim osobinama, svi su jednaki pred zakonom. Jamče se zatim poimence osobne i političke slobode i prava (poput prava na život, zabrane mučenja i prisilnoga rada, prava na pravičan sudski postupak, nepovredivost doma, zaštitu osobnoga i obiteljskoga života, dostojanstva, ugleda i časti, slobodu mišljenja i izražavanja misli, savjesti i vjeroispovijedi itd.). Zasebnim poglavljem jamče se gospodarska, socijalna i kulturna prava kao što su pravo vlasništva, poduzetničke i tržišne slobode, pravo na rad, na socijalnu sigurnost, socijalno osiguranje, zdravstvenu zaštitu i posebnu skrb. Jamči se također pravo na obrazovanje, slobodu znanstvenoga, kulturnoga i umjetničkoga stvaralaštva, kao i pravo na zdrav život u zdravom okolišu. „Ustav Republike Hrvatske. Pročišćeni tekst”, pristup ostvaren 1. 2. 2021., https://www.zakon.hr/z/94/Ustav-Republike-Hrvatske.

3 „Ustav Republike Hrvatske. Pročišćeni tekst”, pristup ostvaren 1. 2. 2021., https://www.zakon. hr/z/94/Ustav-Republike-Hrvatske. 
da 1885. - najvažniji, kao paradigmatski za pravnu stečevinu Europske unije kojom se regulira ta problematika, članak 32. Ustava Republike Hrvatske, kojim se propisuje da svatko tko se zakonito nalazi na području Republike Hrvatske ima pravo slobodno se kretati i birati boravište, zatim da svaki državljanin Republike Hrvatske ima pravo u bilo koje doba napustiti teritorij države i naseliti se trajno ili privremeno u inozemstvu i bilo kada vratiti u domovinu. Pravo kretanja na teritoriju Republike Hrvatske, pravo ulaska u nju i pravo izlaska iz nje može se iznimno ograničiti zakonom ako je to nužno radi zaštite pravnoga poretka ili zdravlja, prava i slobode drugih. ${ }^{4}$ Pravo na slobodu kretanja kao temeljno pravo sadržano je i u članku 45. Povelje Europske unije o temeljnim pravima. U skladu s načelom proporcionalnosti, ograničenja su moguća samo ako su potrebna i ako su zaista u skladu s ciljevima od općega interesa koje priznaje Europska unija ili s potrebom zaštite prava i sloboda drugih osoba. U skladu s Direktivom 2004/38/ EZ Europskoga parlamenta i Vijeća, pravo na slobodno kretanje može se ograničiti radi zaštite određenih javnih interesa, tj. javnoga zdravlja i poretka te javne sigurnosti. $^{5}$

Za temu ovoga rada napose je važno, uzimajući u obzir nedosljednosti i kontradiktornosti u pristupu i provedbi pojedinih epidemioloških mjera i odluka mjerodavnih institucija u Republici Hrvatskoj, Europskoj uniji i zemljama izvan nje, utvrditi osnovanost za dopustivost opravdane sumnje u objektivnost aktualnoga poduzimanja pojedinih epidemioloških mjera i donošenja odluka i mjera s tim u vezi. Kao temelj za to uzima se primjer njihove očite i dokazane zloporabe u prošlosti. Kao predmet istraživanja poslužit će ogledni primjer takve zloporabe - zatvaranje pristupa Moravskoj 1885. sa zapada i istoka, proglašenjem epidemije koja se realno uopće nije dogodila, na temelju dogovorne odluke vlada $\mathrm{Au}$ stro-Ugarske Monarhije i Ruskoga Carstva. Ta je odluka donijeta iz čisto političkih razloga, o kojima će biti više govora kasnije. Moravska se, valja podsjetiti, u to vrijeme, kao i hrvatske zemlje, nalazila u sklopu dualistički ustrojene Austro-Ugarske Monarhije (1867.). Prije prelaska na analizu događaja s tim u vezi svakako držim bitnim naglasiti da svrha ovoga rada nije dovoditi u pitanje ili s bilo kojega aspekta osporavati aktualne epidemiološke odluke i mjere, nego samo utvrditi načelnu dopustivost i legitimnost izražavanja sumnje u njih, propitivanja njihove osnovanosti, zahtijevanja njihova transparentnoga tumačenja i prava na izvođenje racionalnih i logički koncipiranih zaključaka o njihovoj opravdanosti s obzirom na često vrlo različita, pa čak i kontradiktorna stajališta eminentnih virologa, mikrobiologa i molekularnih biologa o spomenutim odlukama i mjerama, kao i utvrđivanje načelne dopustivosti prava javnosti na zahtijevanje kon-

\footnotetext{
„Ustav Republike Hrvatske. Pročišćeni tekst”, pristup ostvaren 1. 2. 2021., https://www.zakon. $\mathrm{hr} / \mathrm{z} / 94 /$ Ustav-Republike-Hrvatske.

5 „Prijedlog PREPORUKE VIJEĆA o koordiniranom pristupu ograničavanju slobodnog kretanja kao odgovor na pandemiju bolesti COVID-19, Bruxelles, 4. 9. 2020.”, 4, pristup ostvaren 2. 2. 2021., https://eur-lex.europa.eu/LexUriServ/LexUriServ.do?uri=COM:2020:0499:FIN:HR:PDF.
} 
senzualnih objašnjenja medicinske struke o učinkovitosti i svrhovitosti njihove primjene. To je posebice važno i upravo nužno jer spomenute epidemiološke mjere u većoj ili manjoj mjeri zadiru u vrlo osjetljivu domenu temeljnih ljudskih prava i sloboda. S tim u vezi držim nadasve uputnim upozoriti i na legitimnost, dapače nužnost propitivanja odluka političkih autoriteta i o svim drugim restriktivnim mjerama koje bitno zadiru u sferu ljudskih prava i sloboda. Na taj problem u filozofskom je diskursu najeksplicitnije upozorila Hannah Arendt, ugledna američka filozofkinja i politologinja, ustvrdivši da je „delegiranje” kritičkoga promišljanja o bitnim pitanjima od javnoga interesa od građana na državne institucije i autoritete, napose u segmentu njihova odlučivanja o najvažnijim pitanjima organizacije političkoga, kulturnoga, gospodarskoga i društvenoga života, vrlo štetno za ljudsko društvo, posebno u situacijama kad se ono suočava $s$ velikim krizama i radikalnim zadiranjem u temeljna zakonska i ustavna prava, te da je to u osnovi temelj uspostave svih totalitarnih poredaka. S tim u vezi upozorila je i na činjenicu da je uspon nacizma u Njemačkoj, čija je gotovo i sama postala žrtvom, najvećim dijelom omogućilo upravo strogo pridržavanje zakona i ne-mišljenje (posvemašnji izostanak propitivanja njihove etičnosti), što je u osnovi bila posljedica zatajivanja rasudne snage. Pritom je također naznačila bitnu povezanost modernih totalitarnih poredaka s naravi birokracije, koja preko administrativnoga aparata pretvara ljude u izvršitelje i puke kotačiće u mehanizmu, na taj ih način dehumanizirajući, što zlo totalitarnih režima, u osnovi, unatoč monstruoznosti i tragičnosti njegovih učinaka, s obzirom na njegovu društvenu i političku genezu čini banalnim. ${ }^{6}$ Arendt je nadalje upozorila na to da je vrijednost rasudne snage napose bitna u kriznim situacijama, koje zahtijevaju nove odgovore na dotad nepoznate fenomene. Naime, u novoj, prije nepoznatoj situaciji, tradicionalni pojmovi, pravila i životne maksime koji se odnose na određenu praksu života postaju neodgovarajući jer se društvena zbilja radikalno promije-

\footnotetext{
${ }_{6}$ Socio-politološki profil nacističkoga zločinca Arendt je minuciozno ocrtala u svojem kultnom, premda u pojedinim segmentima i danas kontroverznom Izvještaju o banalnosti zla (Eichmann u Jeruzalemu), novinskim izvješćima sa suđenja Adolfu Eichmannu u Jeruzalemu 1961. napisanim za mjesečnik The New Yorker. Eichmann je u njezinoj analizi frustriran i ambiciozan birokrat (definira ga i kao „apsolutnog birokrata”) koji je htio savršeno odraditi povjeren mu „posao”, pri čemu ni na koji način nije smatrao spornim da to znači slanje milijuna Židova u smrt. To je, tvrdi Arendt, u esencijalnom smislu određivalo i usmjeravalo njegovo djelovanje, a ne antisemitizam, premda je on bez daljnjega davao temeljno obilježje teroru i genocidnoj praksi nacističkoga režima. Prema Arendt, za holokaust nisu bili ponajprije odgovorni fanatici i zlikovci, što je uobičajena predodžba, nego „obični ljudi”, „ljudi poput nas”, koji su samo „slijedili naredbe” utemeljene na pozitivnim zakonskim propisima nacističkoga režima, uključujući i one rasne, omogućivši time provedbu monstruoznih zločina bez presedana u povijesti, za koje se mnogi, poput Eichmanna, naknadno nisu uopće osjećali odgovornima, držeći da su samo obavljali „svoju dužnost”. Epohalno značenje spomenutoga djela $\mathrm{H}$. Arendt jest u razotkrivanju uzročne povezanosti isključenja refleksivnoga mišljenja, koje ljudska djela, u individualnom promišljanju, dovodi u vezu sa savješću, $s$,inkubacijom” zla i počinjenjem masovnih zločina. Vidi opširnije: Hannah Arendt, Eichmann u Jeruzalemu: izvještaj o banalnosti zla (Zagreb: Naklada Jesenski i Turk, 2020).
} 
nila. Tada, ističe Arendt, najčešće imamo posla s onim što se naziva „kliše”, što znači baviti se ili kretati se u horizontu dotad važećih pojmova, koji su međutim postali nedostatni i za razumijevanje i orijentaciju u svijetu i za nužno potrebne važne izmjene postojećega. ${ }^{7}$ Držim da je znatnim dijelom upravo u tome sadržana bit problema s kojim se trenutačno suočava globalno društvo. Epidemija Covida-19, koja je bez daljnjega nova, prije nepoznata situacija, razotkrila je nedorečenost i krhkost svih prethodnih strategija održivoga razvoja, napose onih vezanih uz krizu liberalnoga kapitalizma. Traže se nova rješenja i napuštanje starih paradigmi, što se u osnovi ne događa, niti ima naznaka da će se u skorijoj budućnosti dogoditi, pa je jedan globalni javnozdravstveni problem ustvari samo razotkrio tešku krizu u kojoj se nalazi suvremena tehnološka civilizacija u najširem gospodarskom, kulturološkom i društvenom smislu. Odgovor za postojeću krizu koji nudi Arendt teško je ostvariv jer ona upućuje na jednu neophodnu racionalnu i duhovnu sposobnost, rasudnu moć, koju definira kao „reflektirajuću rasudnu snagu". ${ }^{8}$ Ona bi, ako dosljedno slijedimo misao H. Arendt, trebala poslužiti kao osnova za oblikovanje novih paradigmi održivoga razvoja, no ta je reflektirajuća rasudna snaga danas gotovo zamrla, odnosno ustuknula pred konceptom logičkoga rasuđivanja na kojem počiva suvremena tehnološka civilizacija, koji uopće ne poznaje reflektirajuću rasudnu snagu kao takvu s obzirom na to da suvremena tehnološka civilizacija principe održivoga razvoja crpi iz sebe same, na osnovi racionalnoga logičkog promišljanja, koje uopće nema refleksivnu dimenziju, isključivo u svrhu ostvarivanja novih, savršenijih gospodarskih rezultata i kreiranja optimalnih paradigmi tehnološkoga razvoja. Pritom se kao logično postavlja pitanje jesu li principi održivoga razvoja koje je iznjedrila suvremena tehnološka civilizacija uopće (ili: još uvijek) u službi čovječanstva i njegovih interesa ili služe isključivo njezinu progresivnome napretku i usavršavanju, čemu se čovjek, ako ne pronađe humanističku alternativu, mora podrediti, odnosno prilagoditi, pa čak i po cijenu zadiranja u njegovu humanu bit (eugeničke ideje o „popravljanju" ljudske vrste genetskom modifikacijom ili pak o stvaranju hibridne humanoidne vrste, „kiborga”, kao spoja organskih i sintetičkih dijelova i dr.). Ovaj prilog, međutim, ni tematski ni opsegovno ne može ulaziti u bilo kakvu dublju analizu spomenutih filozofskih, bioetičkih, socio-politoloških i ekonomskih aspekata krize u kojoj su se aktualno našli liberalni kapitalizam i globalna tehnološka civilizacija, za koju je naznačeno da ju je pandemija Covida-19 s kojom se čovječanstvo upravo suočava samo razotkrila i učinila transparentnom. Svrha mu je upozoriti, napose iz komparativno-historiografske perspektive, na činjenicu da su u ne tako bliskoj prošlosti, ali u vrijeme kad je mikrobiologija već otkrila znatan dio uzročnika teških infektivnih bolesti, proglašavane epidemiološke mjere kojima su se, slično kao i u vrijeme pandemije Covida-19, u bitnom

\footnotetext{
Goran Gretić, „Hannah Arendt i Kant: Pokušaj zasnivanja jedne 'kritike političke rasudne snage”, Politička misao 40 (2003), br. 4: 103.

8 Gretić, „Hannah Arendt i Kant”, 103.
} 
smislu ograničavala temeljna ljudska prava i slobode, a da se poslije razotkrilo da nisu imale nikakvo uporište u medicinskoj znanosti, odnosno da su bile lažne i isključivo politički motivirane. To je svakako bio presedan mnogim zloporabama medicine u 20. stoljeću, od kojih se neke, poput eksperimenata nad ljudima, bez daljnjega mogu pravno kvalificirati i kao zločin protiv čovječnosti. S obzirom na opsegovni, ali i uži tematski okvir ovoga rada, o tome ne može biti govora ni u najsažetijoj formi. ${ }^{9}$ Međutim, ovaj prilog, ne želeći ni na koji način dovoditi u pitanje načelnu opravdanost aktualnih epidemioloških mjera koje se provode $u$ cilju suzbijanja virusa SARS-CoV-2, s obzirom na to da se referira na jednu od najranijih zloporaba medicine u političke svrhe, onu tijekom Velehradske proslave 1885., svakako ima zadatak poslužiti i kao poticaj i ohrabrenje za kritičko promišljanje svih važnijih odluka javnozdravstvenih i političkih institucija u svim situacijama kad se, u cilju suzbijanja infektivnih bolesti i drugih prijetnji, donose odluke i mjere kojima se u bitnom smislu ograničavaju temeljna zakonska i ustavna prava građana, bez prejudiciranja bilo kakve zloporabe glede aktualne pandemije, kakva je bila očita u slučaju epidemije koji se istražuje u ovom radu.

U nastavku priloga koncentrirat ću se na istraživačku temu, zloporabu javnozdravstvenih mjera od strane najviših organa političke vlasti Austro-Ugarske Monarhije, u dogovoru s vlastima Ruskoga Carstva, uoči Velehradske proslave 1885., s ograničenjem kretanja kao glavnom restriktivnom mjerom da bi se onemogućilo masovno slavensko vjersko okupljanje, katolika i grkokatolika iz $\mathrm{Au}$ stro-Ugarske Monarhije te unijata i pravoslavaca iz Ruskoga Carstva, na proslavi u povodu obilježavanja tisućite obljetnice smrti sv. Metoda, proglašenjem lažne epidemije u okolici Velehrada i zatvaranjem pristupa Moravskoj s obje strane, austrijske i ruske. O opstrukciji Velehradske proslave, kojom se napose nastojala afirmirati ideja o sjedinjenju kršćanskoga Istoka i Zapada, događaju u historiografiji gotovo zaboravljenom i prešućenom, ili tek uzgredno spominjanom, bit će više riječi u sljedećem poglavlju.

\section{Velehradska proslava 1885. u korespondenciji biskupa Josipa Jurja Strossmayera s Franjom Račkim te Lujom i Kostom Vojnovićem}

$\mathrm{Na}$ istraživanje događaja u vezi s Velehradskom proslavom potaknulo me je jedno pismo Luja Vojnovića, ${ }^{10}$ povjesničara, diplomata i književnika, istaknu-

\footnotetext{
Vidi o tome opširnije: Sunčana Roksandić Vidlička, Vinko Galiot, „Eksperimenti nad ljudima kao zločin protiv čovječnosti: od nürnberškog medicinskog suđenja do predmeta Pfizer”, Godišnjak Akademije pravnih znanosti Hrvatske 7 (2016), br. 1: 186-253.

10 Lujo Vojnović (Split, 15. travnja 1864. - Zagreb, 18. travnja 1951.). Sin hrvatskoga političara i pravnika Koste Vojnovića (vidi bilj 23.). Gimnaziju pohađa u Splitu, Zagrebu i Dubrovniku, a pravo studira u Zagrebu i Grazu. Zatim djeluje kao sudski pripravnik u Zagrebu i Trstu, odvjetnik u Dubrovniku do 1886., tajnik crnogorskoga kneza Nikole I. Petrovića Njegoša, ministar pravde u crnogorskoj vladi (1899.
} 
toga pripadnika kruga dubrovačkih Srba katolika, ${ }^{11}$ čiju rukopisnu ostavštinu istražujem u sklopu projekta naznačenog na početku ovoga rada, upućeno bosansko-đakovačkom i srijemskom biskupu Josipu Jurju Strossmayeru. ${ }^{12}$ Pismo

- 1903.), opunomoćeni crnogorski predstavnik u Rimu tijekom tzv. Svetojeronimske afere 1901./1902., vršitelj dužnosti šefa kabineta kralja Nikole (nakon proglašenja Kneževine Crne Gore kraljevinom 1910.), crnogorski delegat na Londonskoj mirovnoj konferenciji i akreditirani predstavnik Kraljevine Crne Gore kod britanske vlade (1913./1914.). U Kraljevini Srba, Hrvata i Slovenaca / Jugoslaviji bio je član Demokratske, zatim Samostalne demokratske stranke i Jugoslavenske radikalne zajednice, na čijoj je listi izabran za senatora. Politički se formira nasuprot izrazito hrvatskoj političkoj orijentaciji svojega oca. Bio je istaknuti predstavnik dubrovačkoga srbokatoličkoga kruga. Pisao je političke i književne eseje i povijesne monografije o Dalmaciji (napose Dubrovniku). Vidi opširnije: Zoran Grijak, Stjepan Ćosić, Figure politike: Lujo Vojnović i Robert William Seton-Watson (Zagreb: Hrvatski državni arhiv, 2012).

${ }_{11}$ Genezu fenomena dubrovačkih Srba katolika omogućila je kriza u kojoj se našlo dubrovačko društvo nakon ukidanja Dubrovačke Republike (1808.). Njegovo idejno ishodište nalazi se u teorijama Vuka Stefanovića Karadžića, koji je moderno određenje srpstva izjednačio s uporabom štokavštine, nasuprot prije uvriježenom obrascu po kojem je jedino pravoslavni kršćanin mogao biti Srbinom. Taj je Karadžićev povijesno-lingvistički konstrukt nastao njegovim preuzimanjem iskrivljenih učenja srednjoeuropskih slavista J. P. Šafárika i J. Kollára o štokavštini kao ekskluzivno srpskom narječju. Presudna za prihvaćanje Karadžićevih ideja i nastanak fenomena dubrovačkih Srba katolika ipak je bila činjenica da su te ideje prihvatili i ugledni pripadnik dubrovačke vlastele Medo Pucić (Orsatto Pozza), koji se sa Šafárikom i Kollárom susretao u Veneciji i Padovi, te književnik Matija Ban, koji su prvi put artikulirali srbokatoličke ideje 1848. u dubrovačkom listu L’Avvenire. Uz izražavanje srpske nacionalne ideologije, dubrovački Srbi katolici, koji se početkom 1860-ih još nisu protivili povezivanju Dubrovnika i Dalmacije s Hrvatskom (Medo Pucić u hrvatskom je tisku 1861. čvrsto zastupao ideju hrvatskoga povijesnog i državnog prava), početkom 1880-ih čine obrat i prihvaćaju srpske političke ciljeve, podržavajući srpska prisvajanja Dubrovnika, njegove povijesti, kulture, jezika i književnosti. Ostajući ipak uvijek u sjeni srpske nacionalne ideologije, u kojoj je presudno mjerilo identiteta uvijek bila i ostala protonacionalna pripadnost Srpskoj pravoslavnoj crkvi, srbokatolički se fenomen, od početka usko vezan uz Dubrovnik, premda je imao sljedbenike i u nekim drugim dalmatinskim gradovima (Zadar, Split, Makarska) i Boki kotorskoj, s obzirom na to da je bio lišen bilo kakva znatnijega nacionalnointegracijskog potencijala, od samoga početka sveo na relativno uzak krug pripadnika dubrovačke vlasteoske i građanske elite i u historiografiji ostao zabilježen kao primjer nerealizirane nacionalne ideologije. O tom fenomenu vidi opširnije: Grijak, Ćosić, Figure politike, 19-34.

12 Josip Juraj Strossmayer (Osijek, 4. veljače 1815. - Đakovo, 8. travnja 1905.). Školovao se najprije u Đakovu, a studij teologije te doktorat filozofije završava 1834. u Pešti. U Beču je doktorirao teologiju 1842., a zatim je bio profesor u đakovačkom sjemeništu. Potom je od 1847. bio dvorski kapelan i jedan od trojice ravnatelja Augustineuma (nazivan i Frintaneum po prvom rektoru, prije dvorskom župniku, Jakobu Frintu), carskoga zavoda za višu izobrazbu svećenika u Beču. Na prijedlog bana Josipa Jelačića 1849. imenovan je bosansko-đakovačkim i srijemskim biskupom. Postao je eminentna osoba europske i svjetske kulture nakon svojih glasovitih govora na Prvom vatikanskom saboru, u kojima se, među ostalim, usprotivio donošenju dogme o papinu infalibilitetu i osudi protestantizma. Bio je izrazito politički aktivan kao jedan od vođa Narodne (od 1861.), a potom i jedan od inicijatora osnutka Neodvisne narodne stranke (1880.), premda se aktivno prestao baviti politikom 1873. zbog neuspjele revizije Hrvatsko-ugarske nagodbe (1868.) u njezinu financijskom dijelu. Zalagao se za crkveno jedinstvo katolika i pravoslavaca, posebno kao apostolski vikar katolika u Srbiji (1851. - 1897.). Pripadaju mu neprijeporne zasluge i kao velikome meceni, utemeljitelju najvažnijih hrvatskih modernih kulturnih i znanstvenih ustanova. Vidi opširnije: Hodimir Sirotković, „Život i djelo đakovačkog biskupa Josipa Jurja Strossmayera", u: Međunarodni znanstveni skup Josip Juraj Strossmayer, Zagreb 19. svibnja 2005. - Đakovo 20. svibnja 2005.: povodom 190. obljetnice rođenja i 100. obljetnice smrti. Zbornik radova, ur. Franjo Šanjek (Zagreb: Hrvatska akademija znanosti i umjetnosti, 2006), 25-34. 
je, uz ostala pisma L. Vojnovića Strossmayeru, pohranjeno u Strossmayerovoj ostavštini, ${ }^{13}$ a datira s početka lipnja $1885 .{ }^{14}$ Velehradska proslava u povodu 1000. obljetnice smrti sv. Metoda, na koju se L. Vojnović referira u pismu, bila je najuže povezana s nastojanjima slavenskoga katoličkog episkopata Austro-Ugarske Monarhije da se afirmira starocrkvenoslavenska/glagoljaška liturgija ${ }^{15}$ kao unikatna slavenska komponenta u Katoličkoj crkvi i zajednička baština katoličkih i pravoslavnih Slavena, s ciljem vjerskoga zbližavanja i sjedinjenja crkava. No zbog mogućnosti okupljanja najviših predstavnika slavenskoga katoličkog episkopata Monarhije, kao i zbog toga što su na svečanost, u duhu ideje crkvenoga sjedinjenja, bili pozvani i pravoslavni Slaveni i unijati izvan Monarhije, uključujući one iz Ruskoga Carstva, održavanje te svečanosti u Velehradu austrougarske vlasti shvatile su isključivo kao politički akt s panslavenskim obilježjem. Takav negativan stav austrougarske vlasti zadržale su sve do propasti Austro-Ugarske Monarhije, premda je kasnije, napose u vrijeme sazivanja velikih unionističkih kongresa u Velehradu, 1907. te 1910. i 1911., zamjetan njihov tolerantniji odnos prema manifestiranju ideje o sjedinjenju crkava te općenito prema suradnji katoličkih Slavena Monarhije u sklopu ćirilometodske tradicije. ${ }^{16}$ Pripadnici dviju

${ }^{13}$ Hrvatska (dalje: HR) - Arhiv Hrvatske akademije znanosti i umjetnosti (dalje: AHAZU) - fond Ostavština Josipa Jurja Strossmayera, XI-A, Korespondencija, Pisma Strossmayeru (49), Lujo Vojnović (dalje: F/OJJS, XI-A-49, Voj. Lu.), 1-9.

${ }^{14}$ HR-AHAZU, F/OJJS, XI-A-49, Voj. Lu., 1, L. Vojnović - J. J. Strossmayeru, Zagreb, 5. lipnja 1885.

${ }_{15}$ Za hrvatsku starocrkvenoslavensku liturgiju upotrebljava se i naziv glagoljska (glagoljaška) liturgija jer se hrvatska redakcija starocrkvenoslavenskoga jezika izdvaja od svih drugih time što je jedina sačuvala prvotno glagoljsko pismo.

${ }_{16} \mathrm{~S}$ obzirom na to da se u ovom radu ne može opširnije elaborirati ni sama Velehradska proslava 1885., a kamoli kasniji događaji vezani uz velehradske proslave i osnutak Velehradske akademije, u ovoj će se bilješci dati tek kratak osvrt na najvažnije povijesne činjenice u vezi s tim važnim crkveno-povijesnim fenomenom. Anton Ciril Stojan (Beňov/Převov/, 22. svibnja 1851. - Olomouc, 29. rujna 1923.), nadbiskup Olomouca od 10. ožujka 1921., bio je organizator jubilarne proslave u Velehradu 1885. na temelju odluke tadašnjega nadbiskupa Olomouca, kardinala Friedricha Egona von Fürstenberga. Stojan je pritom odbio udovoljiti nastojanjima ruskih slavenofilskih krugova da svečanost pretvore u sveslavenski kongres. Ta činjenica opovrgava tvrdnje austrougarskih vlasti o panslavenskim intencijama slavenskoga katoličkog episkopata koje su navodno stajale iza ideje o milenijskoj proslavi sv. Metoda. Stojan je bio gorljivi sljedbenik ćirilometodske ideje, češki domoljub i pristaša austroslavističke koncepcije preustroja Austro-Ugarske Monarhije. Godine 1885. utemeljio je Apostolat sv. Ćirila i Metoda pod zaštitom Blažene Djevice Marije, koji je bio okvir za kasnije unionističke kongrese, a 1893. imao je svoje prvo veliko okupljanje. Godine 1910. imao je više od 60 tisuća članova. Stojan je 1907. u Velehradu sazvao Prvi unionistički kongres, na kojem je bilo 76 sudionika iz svih slavenskih katoličkih naroda. Na tom kongresu bio je i ruski obraćenik Leonid I. Fedorov (1879. - 1935.), kasnije biskup i mučenik (na katoličku vjeru prelazi u Rimu 1902., u Bosni je 1911. zaređen za svećenika u grkokatoličkom obredu, 1917. imenovan je egzarhom ruske Grkokatoličke crkve, papa Ivan Pavao II. proglasio ga je blaženim 27. lipnja 2001. zajedno s još 24 ukrajinske žrtve sovjetskoga režima). Stojan se na Prvom unionističkom kongresu zauzeo za približavanje katolika i pravoslavaca, anticipirajući (poput biskupa Strossmayera) ekumenističke ideje. Zbližavanje s Evangeličkom crkvom nije se na Velehradskom unionističkom kongresu 1907., kao ni na onima iz 1910. i 1911., uopće uzimalo u raspravu. Prvi svjetski rat okončao je održavanje velehradskih unionističkih kongresa. Tijekom 
vladajućih nacija, austrijski Nijemci i Mađari, držali su panslavizam te općenito ideju slavenske uzajamnosti i suradnje prijetnjom za održanje dualističkoga ustroja Austro-Ugarske Monarhije, u kojoj su Slaveni tvorili većinu, ${ }^{17}$ te su i Velehradskoj proslavi težili na svaki način umanjiti njezin slavenski značaj, a 1885.

rata Stojan je utemeljio Institut sv. Ćirila i Metoda za slavenske misije pri isusovačkom kolegiju u Velehradu, koji je 1919. uzdignut na rang papinskoga instituta i afiliran Papinskom orijentalnom institutu u Rimu. Nakon Stojanove smrti 1923. djelovanje na tom planu privremeno je obustavljeno, no ubrzo su (1924., 1927., 1932. i 1936.) uslijedili glavni unionistički kongresi (Haupt-Unions-Kongresse) pod zaštitom čehoslovačke vlade, s oko 500 sudionika, među kojima je bila sve manja zastupljenost pravoslavaca. Metropolit Grkokatoličke ukrajinske crkve Galicije Andrej Šeptyckyj, koji je od 1910. do 1939. predsjedavao Velehradskom akademijom, hodočašćima u Velehrad daje snažniji nacionalno-politički karakter. Posljednje hodočašće u Velehrad tijekom Drugoga svjetskog rata održano je 1940. kao nacionalna češka manifestacija. Nakon atentata na Heinricha Heydricha, visokoga nacističkog dužnosnika, Reichsprotektora Češke i Moravske, u Pragu 1942. i njegove smrti dva dana poslije (4. lipnja 1942.), hodočašća u Velehrad su zabranjena. Poslije Drugoga svjetskog rata uslijedila su 1946. i 1947. unionistička vijećanja u Velehradu, no nakon toga komunističke vlasti Čehoslovačke zabranile su ih. Smetala im je napose vjerska, ekumenistička narav velehradskih okupljanja, ali nastojale su u njegovanju kulture reduciranoga sjećanja na taj fenomen sačuvati simboliku njihova sveslavenskoga značaja, što je imalo za posljedicu pseudohistoriografske prikaze velehradskoga fenomena u komunističkoj Čehoslovačkoj. Istovremeno je nastala takozvana velehradska ideja (eine sogenannte Velehrad-Idee) u Sjedinjenim Američkim Državama, gdje su 1956., 1957. i 1959. održani unionistički kongresi. U godinama koje su prethodile Praškom proljeću 1968. počele su se u Slovačkoj organizirati skupštine u dvorcu Devin u Bratislavi koje su se zauzimale za ideju slavenskoga internacionalizma, a 1967. sasvim je eksplicitno iznijeta ideja organiziranja ćirilometodskoga nacionalnog hodočašća (eine kyrillomethodianische Nationalwallfahrt). Godine 1963. papa Ivan XXIII. istaknuo je veliko značenje velehradskih unionističkih kongresa. Papa Ivan Pavao II. u svojem je apostolskom pismu Egregiae virtutis (1980.) sv. Ćirila i Metoda proglasio nebeskim suzaštitnicima (uz sv. Benedikta) cijele Europe. Tijekom Praškoga proljeća 1968. bivšim grkokatoličkim župama bilo je dopušteno vratiti se u zajedništvo s Rimom. Nakon pada komunizma 1989. većina crkvene imovine vraćena je slovačkoj Grkokatoličkoj crkvi. Za grkokatolike u Češkoj osnovan je poseban Apostolski vikarijat, uzdignut 1996. na razinu egzarhata. U Slovačkoj je papa Ivan Pavao II. 1997. osnovao Apostolski egzarhat u Košicama. Papa Benedikt XVI. podigao ga je na razinu eparhije 30. siječnja 2008., a u isto vrijeme podignuta je nova eparhija bizantskoga obreda u Bratislavi. On je također podigao Prešov na razinu stolne arhieparhije, učinivši slovačku Grkokatoličku crkvu sui iuris Crkvom. Nakon dugih priprema, započetih 1980., u Velehradu je 1985. održana velika jubilarna svečanost u povodu 1100. obljetnice smrti sv. Metoda, na kojoj su u velikom broju sudjelovali slovački i moravski katolici. Papa Ivan Pavao II. objavio je 2. lipnja 1985. encikliku Slavorum apostoli povodom obljetnice evangelizacije sv. Ćirila i Metoda, posvećenu misijskom poslanju Crkve. Papa u njoj pokazuje važnost sv. Ćirila i Metoda u širenju vjere, kulture i ekumenizna. Uz opće slavensko i šire europsko značenje sv. Ćirila i Metoda i velehradskih proslava te potonjih unionističkih kongresa, autori studije čiji je sadržaj ukratko prikazan u ovoj bilješci posebice ukazuju na njihovu važnost kao „katalizatora nacionalnih pokreta” u Slovačkoj, Moravskoj i Češkoj. Vidi opširnije: Markus Peter Beham, Stefan Rohdewald, „Kyrill und Method", u: Religiöse Erinnerungsorte in Ostmitteleuropa. Konstitution und Konkurrenz im nationenund epochenübergreifender Zugriff, ur. Joachim Bahlcke, Stefan Rohdewald i Thomas Wünsch (Berlin: Akademie Verlag, 2013), 473-493.

17 U Austro-Ugarskoj Monarhiji dvije vladajuće nacije, austrijski Nijemci i Mađari, bili su u manjini $(42,9 \%)$ u odnosu na slavensku većinu (47,8\%). Preostalih 9,3\% činili su pripadnici drugih naroda (Rumunji, Talijani, Židovi i dr.). „Austro-Ugarska”, Hrvatska enciklopedija, mrežno izdanje, Leksikografski zavod „Miroslav Krleža”, pristup ostvaren 27. 4. 2021., https://enciklopedija.hr/natuknica. aspx?ID=4697. 
u tome su i uspjeli. S obzirom na hrvatske zemlje, politički podijeljene u sklopu dualistički ustrojene Austro-Ugarske Monarhije, austrougarske su vlasti afirmaciju starocrkvenoslavenske liturgije smatrale također iznimno opasnom jer je ona bila zastupljena na čitavome njihovu prostoru te je stoga bila i važan kulturnokohezivni i nacionalnointegrativni čimbenik u hrvatskome nacionalnointegracijskom procesu tijekom 19. stoljeća. ${ }^{18}$ Pritom su nastojanja austrougarskih vlasti za onemogućivanje odlaska hrvatskoga hodočašća na Velehradsku proslavu naišla u hrvatskim zemljama i na podršku pojedinih oporbenih političkih stranaka, koje su se iz svojih načelnih programskih razloga protivile bilo kakvoj formi slavenske uzajamnosti i suradnje. Naime, osim austrijske te ugarske i njezinim intencijama odane Hrvatsko-slavonske zemaljske vlade, na čelu koje se od 1883. do 1903. nalazio ban Károly (Dragutin) Khuen-Héderváry, protiv održavanja Velehradske proslave 1885. bila je i Stranka prava, uz Neodvisnu narodnu stranku najutjecajnija hrvatska oporbena stranka. Njezin prvak Ante Starčević s tim u vezi u pravaškoj je Slobodi (br. 44/1885) napisao da katolici u Hrvatskoj, Češkoj, Poljskoj i dr. nemaju mnogo zajedničkoga te da je Velehradska proslava ustvari politička demonstracija pod krinkom vjerozakona. ${ }^{19}$ Stranka prava i inače je oponirala svim inicijativama usmjerenim prema sjedinjenju crkava, pa tako i ovoj iz 1885., koju su napose podržavali Strossmayer i Franjo Rački, odnosno Neodvisna narodna stranka, koja se od svojega osnutka 1880. nalazila pod snažnim Strossmayerovim utjecajem. Pritom na držanje Stranke prava s tim u vezi nije ni najmanje utjecala činjenica da je Starčević u to vrijeme imao pozitivan stav o Ruskom Carstvu i njegovoj mogućoj ulozi u rješavanju hrvatskoga pitanja, jer se to odnosilo isključivo na ulogu Ruskoga Carstva u odnosima među europskim velesilama, glede kojega je Starčević od kraja 1870-ih do 1889. gajio velike nade, očekujući da će se politički angažirati u obuzdavanju širenja političkoga utjecaja Njemačkoga Carstva. ${ }^{20} \mathrm{~S}$ takvim shvaćanjem uloge Rusije Starčevića i

\footnotetext{
18 Vidi o tome opširnije: Zoran Grijak, „O nacionalno-političkim aspektima zahtjeva za afirmacijom glagoljaške liturgije u hrvatskim zemljama od sredine 19. do početka 20. stoljeća”, Croatica Christiana periodica 43 (2019), br. 83: 81-119.

${ }_{19}$ Josip Balabanić, Josip Kolanović, prir., Korespondencija Josip Juraj Strossmayer - Serafin Vannutelli, 1881-1887 (Zagreb: Hrvatski državni arhiv; Kršćanska sadašnjost; Dom i svijet, 1999), 481, bilj. 1.

${ }_{20}$ Političke simpatije A. Starčevića bile su u početku okrenute Francuskoj, iz čijega je sukoba s Njemačkom očekivao oslobođenje hrvatskoga naroda. Njegov zaokret prema Rusiji započinje uoči Berlinskoga kongresa (1878.), što najočitije dolazi do izražaja u spisu $\mathrm{Na}$ čemu smo. Međutim, tek nizom članaka u Slobodi u travnju i svibnju 1879. zauzima proruski smjer. Starčevićevo rusofilstvo slabi 1889., kad započinje kritizirati rusku diplomaciju zbog vođenja neprijateljske politike prema Velikoj Britaniji, a ne Njemačkoj. Vidi: Mato Artuković, „Ante Starčević i Židovi (prema pisanju lista Sloboda)", Časopis za suvremenu povijest 42 (2010), br. 2: 490. Stjepan Matković, analizirajući iz drugačijega rakursa problem odnosa Stranke prava i A. Starčevića prema Rusiji, ustvrdio je da je kod njih najprije bio zastupljen antislavenski sentiment, ali ne dugotrajno, jer je on bio napose posljedica pretpostavke da pristaše slavenstva više izlaze ususret srpskome nacionalizmu nego hrvatskim nacionalnim interesima. Taj je kritički odnos bio izrazito vidljiv u vrijeme odvijanja Istočnoga pitanja (1875. - 1878.). Međutim, krajem 1870-ih pravaši su počeli uzimati u obzir i ulogu Rusije pri oblikovanju samostalnih
} 
Stranke prava, kao glavnoga oponenta širenju njemačkoga utjecaja na jugoistočnu Europu, nije međutim ni na koji korespondirala ideja o slavenskom zbližavanju i sjedinjenju crkava koju je Starčević, napose zbog mogućnosti zloporabe slavenskih i južnoslavenskih ideja za promicanje ciljeva velikosrpskoga programa, držao prijetnjom oblikovanju neovisne hrvatske države, čemu su bila usmjerena politička nastojanja Stranke prava. Uzevši u obzir navedeno, pravaši su se usprotivili održavanju Velehradske proslave, ali samo dijelom iz identičnih razloga kao austrougarske vlasti, koje su pritom imale ponajprije u vidu da se Velehradskom proslavom afirmiraju panslavenske ideje, odnosno ruske pretenzije prema katoličkim zemljama Monarhije, kao i prema Bosni i Hercegovini. Osobito je Bosna i Hercegovina, nakon što je na Berlinskom kongresu 1878. okupacijski mandat za nju povjeren Austro-Ugarskoj Monarhiji, ${ }^{21}$ bila predmet kontinuiranih vanjskopolitičkih ambicija Ruskoga Carstva, koje je, potičući velikosrpske aspiracije za njom, težilo ostvariti svoju penetraciju na Balkan i topla mora. ${ }^{22}$

Problematika Velehradske proslave ovdje će se analizirati ponajprije na temelju arhivskoga gradiva, pri čemu uz korespondenciju između Strossmayera i Račkoga te L. Vojnovića i Strossmayera posebice važnu ulogu ima korespondencija između Strossmayera i Lujova oca Kosta Vojnovića, uglednoga hrvatskog povjesničara, pravnika i političara. ${ }^{23}$ Potonja je korespondencija u znanstvenom smislu

država na Balkanu. Tada nastupa vrijeme rusofilstva, koje se nije odražavalo samo u političkom životu nego i u visokom vrednovanju ruske kulture pojedinih istaknutih pravaša. Otad nadalje nijedan pravaški prvak nije potpuno zanemarivao ruski utjecaj na šira politička kretanja, što je bilo usko povezano i s intenzitetom austrougarskih odnosa prema Rusiji u sklopu općih kretanja u Jugoistočnoj Europi. Vidi: Stjepan Matković, „Ambivalentnost pravaškog odnosa prema Rusiji i Rusima”, Međunarodna znanstvena konferencija HRVATSKA - RUSIJA / ХОРВАТИЯ - РОССИЯ. Povijesne veze i iskušenja uzajamnosti, Zagreb, 24. svibnja 2018., Kratki sažetak referata, 20.

${ }^{21}$ O Berlinskom kongresu vidi opširnije: William Norton Medlicott, The Congress of Berlin and After: A Diplomatic History of the Near Eastern Settlement, 1878-1880 (London: Methuen and Company, 1938); William Norton Medlicott, „Diplomatic Relations after the Congress of Berlin”, Slavonic and East European Review 8 (1929), br. 22: 66-79.

22 Vidi o tome opširnije: Zoran Grijak, Politička djelatnost vrhbosanskog nadbiskupa Josipa Stadlera (Zagreb; Sarajevo: Hrvatski institut za povijest; Dom i svijet; Vrhbosanska nadbiskupija, 2001), 34-44, 430-435, 567-773.

${ }^{23}$ Konstantin (Kosta, Kosto) Vojnović (Herceg Novi, 2. ožujka 1832. - Dubrovnik, 20. svibnja 1903.). Nakon svršetka studija prava u Beču 1855., doktorirao je u Padovi 1856. U siječnju 1855., još kao student, oženio se Dubrovkinjom firentinskoga podrijetla Marijom de Serragli. Iste godine odlazi s njom u Veneciju i Padovu (ondašnje Lombardijsko-Venetsko Kraljevstvo pod austrijskom vlašću). Ondje im se rodila kći Katarina (Katica) (Venecija, 1856. - Dubrovnik, 1928.), koja je pohađala glazbene škole u Milanu, Münchenu i Zagrebu te stekla zvanje profesora glazbe i pravo privatne pouke na glasoviru. Vrativši se u Dubrovnik K. Vojnović ulazi u odvjetničku kancelariju dr. Radmillija. Godine 1957. rodio mu se sin Ivo, ugledni hrvatski književnik (Dubrovnik, 1857. - Beograd, 1929.). Godine 1858. otvorio je odvjetnički ured u Splitu. Bio je među pokretačima hrvatskoga narodnog pokreta u Dalmaciji. Njegov spis Un voto per l'unione ovvero gl'interessi della Dalmazia nella sua unione alla Croazia e all'Ungheria (Split, 1861.) imao je programsko značenje za hrvatski narodni pokret u Dalmaciji. Godine 1859. imenovan je tajnikom Trgovačke komore u Splitu. Od 1863. do 1875. bio je 
znatno relevantnija od one Strossmayera i L. Vojnovića, kako općenito tako i s obzirom na problematiku koja se ovdje istražuje, a dosad je, nažalost, u hrvatskoj historiografiji objavljivana i analizirana samo fragmentarno, ne uključujući dijelove koji se analiziraju u ovome radu. ${ }^{24}$ Strossmayerovu korespondenciju sa L. Vojnovićem treba shvatiti napose u sklopu bliskih Strossmayerovih veza s njegovim ocem Kostom, kao i cijelom obitelji Vojnović. Pritom svakako treba upozoriti na to da Strossmayer u vrijeme svojega korespondiranja sa L. Vojnovićem (1885. - 1901.), koje se odvijalo u počecima Lujova odvjetničkoga i književno-povijesnoga djelovanja te njegova obnašanja dužnosti tajnika crnogorskoga kneza Nikole I. Petrovića Njegoša, nije znao da ovaj pripada krugu dubrovačkih Srba katolika. Za to doznaje tek u vrijeme tzv. Svetojeronimske afere 1901./1902., kad se L. Vojnović kao opunomoćeni predstavnik Kneževine Crne Gore pri Svetoj Stolici sasvim otvoreno zauzeo za protuhrvatske interese, nastojeći da se Zavodu sv. Jeronima u Rimu uz hrvatsko prizna i srpsko ime. ${ }^{25}$ Nakon toga Strossmayer je s njim prekinuo svaki kontakt.

Dana 5. srpnja 1885. obilježavala se 1000. godišnjica smrti sv. Metoda. ${ }^{26}$ Tom je prigodom biskup Strossmayer svoju korizmenu okružnicu posvetio poglavito

zastupnik Narodne stranke u Dalmatinskom saboru u Zadru. Godine 1864. rodio mu se drugi sin, Lujo (Split, 1864. - Zagreb, 1951.), povjesničar, diplomat i političar, a 1866. druga kći, Eugenija (Gjene) (Split, 1866. - Pariz, 1956.), kasnije književnica (objavljivala je pod pseudonimom Kristijana Solveig), koja se udala za francuskoga pravnika, povjesničara i diplomata Charlesa Loiseaua. Najmlađa kći Kristina umrla je u dobi od dvije godine (1868. - 1870.). Na poziv biskupa Strossmayera K. Vojnović 1874. dolazi u Zagreb i preuzima katedru građanskoga prava na Pravnom fakultetu novoutemeljenoga Sveučilišta u Zagrebu. Bio je i rektor Sveučilišta 1878./1879. te zastupnik u hrvatskom Saboru (1878. - 1881., 1881. - 1884.). Istaknuo se kao potpredsjednik i pisac programa Neodvisne narodne stranke Što hoće neodvisna narodna stranka? (Zagreb, 1884.). Zbog saborskoga govora o riječkom pitanju privremeno je ostao bez službe (1881. - 1882.). Bio je među najistaknutijim oponentima režima bana Khuen-Héderváryja, koji ga je 1891. uklonio sa Sveučilišta i prijevremeno umirovio. Vidi: HR - Hrvatski državni arhiv, Zagreb - fond 781 - Obitelj Vojnović, Spisi za historijat obitelji.

24 Vidi: Tomislav Markus, „Korespondencija Josipa J. Strossmayera i Koste Vojnovića kao povijesni izvor”, Časopis za suvremenu povijest 36 (2004), br. 2: 581-595; Tomislav Markus, „Korespondencija Strossmayer-Vojnović: Izabrani dokumenti", Zbornik Odsjeka za povijesne znanosti Zavoda za povijesne i društvene znanosti Hrvatske akademije znanosti i umjetnosti 25 (2007): 331-383.

${ }_{25}$ Vidi o tome opširnije: Zoran Grijak, „Barski nadbiskup Šimun Milinović (1886. - 1910.) i svetojeronimska afera", u: Hrvatsko-crnogorski dodiri / crnogorsko-hrvatski dodiri: identitet povijesne i kulturne baštine Crnogorskog primorja, ur. Lovorka Čoralić (Zagreb: Hrvatski institut za povijest; Matica hrvatska, 2009), 489-520.

${ }^{26}$ U povodu velikih proslava tisućgodišnjice dolaska sv. Ćirila i Metoda u Moravsku (863. - 1863.) na poziv moravskoga kneza Rastislava upućen bizantskom caru Mihaelu III., čime je započela njihova misija među Slavenima, papa Pio IX. dopustio je 1863. vjernicima u Češkoj, Moravskoj i Hrvatskoj slaviti sv. Ćirila i Metoda na dan 5. srpnja. Papa Lav XIII. u enciklici Grande munus (30. rujna 1880.), kojom je proširio njihovo štovanje na opću Crkvu, potvrdio je odluku svojega prethodnika da se njihov blagdan ima slaviti 5. srpnja. Inače, sv. Ćiril (svjetovno ime Konstantin) rođen je u Solunu 826./827., a umro 14. veljače 869. u Rimu. Sv. Metod (svjetovno ime Mihael) rođen je u Solunu oko 815., a umro 6. travnja 885. u Moravskoj. Naziva ih se i Solunskom braćom, Svetom braćom i Slavenskim apostolima. Pravoslavna crkva blagdan sv. Ćirila i Metoda slavi 11. svibnja po julijanskom, odnosno 24. svibnja po 
tom događaju. ${ }^{27}$ On je i u svojim prethodnim okružnicama često upozoravao na važnost djelovanja sv. Ćirila i Metoda za vjersku i kulturnu povijest slavenskih naroda i istaknutu ulogu ćirilometodske baštine u nastojanjima Svete Stolice za postizanje crkvene unije s pravoslavnim crkvama, napose proširenjem uporabe starocrkvenoslavenske liturgije u sklopu Katoličke crkve kao zajedničke baštine dviju crkava. ${ }^{28}$ Korizmenom okružnicom iz 1885. Strossmayer je pozvao svoju dijecezu, ali i cijeli hrvatski narod, da se u sklopu obilježavanja 1000. obljetnice smrti sv. Metoda pridruži velikom slavenskom hodočašću te dao kratak životopis sv. Metoda, opisujući ga prvenstveno kao panonsko-moravskoga biskupa, kojega je nasljednik na srijemskoj biskupskoj stolici. ${ }^{29}$

Lujo Vojnović očito je, što je vidljivo iz njegova pisma Strossmayeru od 5. lipnja 1885., gajio uvjerenje da će ovaj otići u Moravsku na veliku Velehradsku proslavu 5. srpnja 1885., što se međutim zbog okolnosti o kojima će biti više riječi u nastavku rada nije ostvarilo. ${ }^{30}$ Planovi moravskoga katoličkog episkopata glede organizacije Velehradske proslave bili su zaista vrlo zamašni. Željeli su da se na svečanosti okupe hodočasnici iz svih slavenskih naroda Austro-Ugarske Monarhije, pa čak i iz susjedne Rusije. Hrvatsko hodočašće trebao je predvoditi biskup Strossmayer. No, vladajući austrougarski krugovi ni u kojem slučaju nisu bili spremni to dopustiti, držeći da se u osnovi ne radi o vjerskoj proslavi, nego o političkoj manifestaciji panslavenskih ideja koje otvaraju Rusiji put za prodor

gregorijanskom kalendaru. Vidi opširnije o njihovu životu i djelovanju: „Ćiril i Metod, sv.”, Hrvatska enciklopedija, mrežno izdanje, Leksikografski zavod „Miroslav Krleža”, pristup ostvaren 6. 4. 2021., https://www.enciklopedija.hr/natuknica.aspx?ID=13585.

27 Vidi: „Korizmena poslanica Josipa Jurja Strossmayera - izvadak (4. veljače 1885.)”, u: Dokumenti o sv. Ćirilu i Metodu (Zagreb: Kršćanska sadašnjost, 1985), 59-68, 74-174; Dvije korizmene okružnice dvaju hrvatskih biskupa - J. J. Štrosmajera i J. Posilovića (Zagreb: F. Fišer i dr., 1885).

28 Vidi: „Okružnica biskupa Josipa Jurja Strossmayera od 9. svibnja 1863.”, „Okružnica Josipa Jurja Strossmayera, biskupa đakovačkog od 5. lipnja 1863.”, „Druga okružnica o sv. Ćirilu i Metodu biskupa Josipa Jurja Strossmayera (iz 1881. godine)", u: Dokumenti o sv. Ćirilu i Metodu, 59-68, 74-174; Milica Lukić, „Ćirilometodske okružnice biskupa J. J. Strossmayera u Glasniku Biskupija Bosanske i Sriemske od 1873. do 1900. godine”, u: Muka kao nepresušno nadahnuće kulture - Vukovar kao paradigma muke. Zbornik radova 4. međunarodnoga znanstvenog simpozija, ur. Jozo Čikeš (Zagreb: Udruga Pasionska baština, 2004), 146-161.

29 Vidi: Milica Lukić, „Strossmayerov projekt obnove ćirilometodske baštine”, Anali Zavoda za znanstveni i umjetnički rad u Osijeku 27 (2011): 88.

${ }^{30}$ U svojem prvom pismu biskupu Strossmayeru, prisjećajući se sa zahvalnošću i ushitom nekoliko dana koje je s ocem Kostom proveo kod njega u Đakovu, L. Vojnović očituje nakanu zahvaliti mu na dobrohotnosti koju mu je pritom iskazao, nakon njegova povratka iz Velehrada u Zagreb, a prije odlaska u Đakovo: „Molim da Vam na povratku s Vašega teškoga i slavnoga puta zahvalim za svu onu dobrotu kojom me obasula, mene nevrijedna i nedostojna mladića, preuzvišenost Vaša kao [i] nekoliko p[r]esretnijeh dana. Može mi doista svijet zavigjeti sreću što sam s ocem i sa zaštitnikom naroda proveo takve nezaboravne časove i što sam mogao crpiti u njegovome velikom srcu, u njegovoj ljubavi za domovinu, po koji tračak i ja od toga srca i od te ljubavi." HR-AHAZU, F/OJJS, XI-A-49, Voj. Lu., 1, L. Vojnović - J. J. Strossmayeru, Zagreb, 5. VI. 1885. 
na slavenska područja Monarhije, ugrožavajući time njezin opstanak. Ruska vlada također se protivila isticanju slavenskoga obilježja Velehradske proslave jer je smatrala da bi to djelovalo poticajno na sklapanje crkvene unije pravoslavnih crkava sa Svetom Stolicom, čemu se posebice oštro protivila Ruska pravoslavna crkva. Pravoslavne crkve, napose Ruska, ali i Ekumenska patrijaršija sa sjedištem u Carigradu, kao i Srpska pravoslavna crkva, bile su protiv Velehradske proslave i zato što su se oštro protivile interpretaciji Katoličke crkve da dvojica slavenskih svetaca pripadaju zajedničkoj baštini dviju crkava. ${ }^{31}$

Da bi onemogućile hrvatsko hodočašće u Velehrad, austrougarske su vlasti najprije zabranile put $\mathrm{u}$ Velehrad hrvatskim katoličkim velikodostojnicima koji su trebali predvoditi misno slavlje 5. srpnja, a zatim su, pod izlikom da se u okolici Velehrada pojavila epidemija, zabranile put prema Moravskoj svim slavenskim hodočasnicima iz drugih dijelova Monarhije, napose Hrvatima i Slovencima, te u dogovoru s ruskom vladom zatvorile državnu granicu prema Ruskom Carstvu, čime su onemogućile pristup Moravskoj i hodočasnicima s njegova teritorija. ${ }^{32}$ Austrijska vlada upozorila je bečkoga nuncija Serafina Vannutellija ${ }^{33}$ da ne želi

31 Stajalište prema kojem su sv. Ćiril i Metod podjednako sveci Pravoslavne kao i Katoličke crkve napose je nastojao osporiti Nikodim Milaš (Šibenik, 4. travnja 1845. - Dubrovnik, 20. ožujka 1915.), zadarski episkop (episkop dalmatinski) od 1890., u djelu koje je napisao kao odgovor na encikliku pape Lava XIII. Grande munus od 30. rujna 1880., kojom su sv. Ćiril i Metod proglašeni svecima opće Crkve. Vidi: Nikodim Milaš, Slavenski apostoli Kiril i Metodije i istina pravoslavlja: Povodom rimskog pokreta u 1880-81 god. protivu pravoslavne crkve (Zadar: Pečatnja Iv. Vodicke, 1881). Uz osporavanje pravovjernosti Katoličkoj crkvi, kao i prava Svetoj Stolici na proglašenje sv. Ćirila i Metoda svecima opće Crkve na temelju tvrdnje da se radi isključivo o svecima Pravoslavne crkve, Milaš krajnje tendenciozno, bez bilo kakva potkrepljivanja svojih teza, povezuje istočnu crkvenu politiku Svete Stolice, usmjerenu prema crkvenom sjedinjenju kršćanskoga Istoka i Zapada, s propašću Papinske Države 1870. Prema njegovoj interpretaciji, propast Papinske Države tako je temeljito narušila ugled Rima na Zapadu da se on, kako bi nadoknadio taj gubitak, silom prilika, a ne potaknut iskrenim vjerskim nakanama, okrenuo Slavenima i kršćanskom Istoku: „Za Rim danas političko obzorje sjeverne i zapadne Evrope nije zgodno. Na Zapad on malo nade položiti može, da će mu na [pri, op. a.] ruci biti, da sebe uzpostavi na onaj stupanj, na kome je on do 13. septembra 1870. godine bio [pijemonteška vojska osvojila je Rim 20. rujna 1870., op. a.]. Malo, vrlo malo imaju obzira prema njemu čak i oni koji su mu najbliži, koji se njegovima zovu. Pri takovome stanju treba tražiti već ne na Zapadu pomoći. Slavenima, kao narodu čilom, nezaraženom zapadnjačtvom prorokuju, da će oni morati [...] kulturnom silom da preporode istrunuli Zapad. [...] to kažu noviji rimski naučenjaci, to kaže i gd. biskup Štrosmajer; [...].” Milaš, Slavenski apostoli Kiril i Metodije, „Predgovor”, VI [izvornik na ćirilici].

32 „U dogovoru s ruskom vladom zatvorili su državnu granicu, razglasili da se u okolici Velehrada pojavila epidemija te da je pristup u ta područja svima zabranjen.” Andrija Šuljak, „Biskup Josip Juraj Strossmayer i ćirilometodsko-glagoljska baština”, Diacovensia: teološki prilozi 2 (1994), br. 1: 288.

33 Serafin Vannutelli (Genazzano, 26. studenog 1834. - Rim, 19. kolovoza 1915.). Za svećenika je zaređen 1860. Kad se nadvojvoda Ferdinand Maksimilijan Habsburški 1864. proglasio carem Meksika (ubijen 1867. po nalogu predsjednika meksičke republikanske vlade u egzilu Benita Pabla Juáreza), s nuncijem Pier-Francescom Megliom odlazi u Meksiko. Nakon biskupskoga posvećenja 1869. bio je apostolski delegat u Srednjoj Americi do 1875. Od 1875. do 1880. bio je nuncij u Belgiji, a od 1880. do 1887. u Beču. Kao bečki nuncij imao je nadasve važnu ulogu u procesu obnove redovite katoličke hijerarhije u Bosni i Hercegovini (1881.). Tada razvija i vrlo dobre odnose s biskupom Strossmayerom, 
masovna okupljanja, a napose da se energično protivi sudjelovanju na Velehradskoj proslavi katoličkih velikodostojnika iz drugih slavenskih zemalja Monarhije. Zahtijevala je da se slavlja održe po pojedinim regijama, odnosno crkvenim pokrajinama, no da svakako budu svečanija nego kod pravoslavnih te da ih slave ne samo Slaveni nego i drugi narodi kako bi se oslabilo njihovo slavensko obilježje. Nuncija se posebice upozorilo na to da treba onemogućiti putovanje u Velehrad senjsko-modruškom biskupu Jurju Posiloviću. ${ }^{34}$ On je naime, s obzirom na to da je u njegovoj biskupiji bila u uporabi i starocrkvenoslavenska liturgija rimsko-slavenskoga obreda ${ }^{35}$ i da se njome suvereno služio, trebao predvoditi svečano starocrkvenoslavensko liturgijsko slavlje u Velehradu u povodu 1000. godišnjice smrti sv. Metoda 5. srpnja 1885. ${ }^{36} \mathrm{Iz}$ istoga razloga put u Velehrad zabranjen je i križevačkom grkokatoličkom biskupu Iliji Hraniloviću (1883. - 1889.), koji je starocrkvenoslavensku liturgiju služio u grčko (bizantsko)-slavenskom obredu, a trebao je zajedno s Posilovićem slaviti misu u Velehradu, o čemu doznajemo iz Strossmayerove korespondencije s Račkim, o kojoj će biti više riječi u nastavku rada.

Premda je L. Vojnović bio upoznat s namjerom biskupa Strossmayera da predvodi hrvatsko hodočašće u Velehrad, ponajprije od svojega oca K. Vojnovića, koji je o tome sa Strossmayerom učestalo korespondirao, očito je da nije imao detalj-

s kojim u obimnoj korespondenciji na latinskom jeziku, u cijelosti prevedenoj na hrvatski, razmjenjuje stajališta o modalitetima crkvenoga preustroja u Bosni i Hercegovini i mnogim drugim pitanjima, napose onima vezanim uz sjedinjenje crkava. Godine 1887. imenovan je kardinalom, a 1888. protektorom Zavoda sv. Jeronima u Rimu. Vidi: Balabanić, Kolanović, Korespondencija Josip Juraj Strossmayer - Serafin Vannutelli.

34 Juraj Posilović (Ivanić-Grad, 24. travnja 1834. - Zagreb, 26. travnja 1914.). Zaređen je za svećenika 1858., a doktorat bogoslovlja iz područja biblijskih disciplina obranio je u Beču 1861. Bio je urednik Zagrebačkoga katoličkog lista od 1872. do 1875. Godine 1876. izabran je za senjsko-modruškoga biskupa, a 1894. za zagrebačkoga nadbiskupa. Znatno je pridonio uspostavi starocrkvenoslavenske liturgije u Senjsko-modruškoj biskupiji 1893. Vidi: Fran Barac, „Nadbiskup Dr. Juraj Posilović”, Katolički list 65 (1914), br. 18: 213-218; Agneza Szabo, „Juraj Posilović 1894. - 1914.”, u: Zagrebački biskupi i nadbiskupi, ur. Franko Mirošević (Zagreb: Školska knjiga, 1995), 481-486.

35 Službeno crkveno dopuštenje za uporabu glagoljaške liturgije u Senjsko-modruškoj biskupiji Sveta Stolica dala je tek 1893. Ono je korespondiralo s objavljivanjem glagoljaškoga misala Dragutina Antuna Parčića Rimski misal slavenskim jezikom (Rim: S. Congr. de Propaganda Fide, 1893), a bilo je jedinstveno po tome što se protezalo na područje cijele Senjsko-modruške biskupije, dok je u svim ostalim dijecezama u hrvatskim zemljama, napose u Dalmaciji, Hrvatskom primorju te na Kvarneru i u Istri, gdje je bilo najviše glagoljaških župa, svaka ponaosob morala potvrditi svoje pravo na njezinu uporabu na temelju vrlo restriktivnih odredbi dekreta Svete Stolice s tim u vezi. Pritom svakako treba upozoriti na to da je Parčićev misal bio namijenjen i Barskoj nadbiskupiji, kojoj je Sveta Stolica 1887., samo godinu dana nakon njezine obnove i sklapanja konkordata s Kneževinom Crnom Gorom, potvrdila privilegij uporabe starocrkvenoslavenske liturgije, također na čitavome njezinu prostoru, bez bilo kakvih ograničenja. Vidi o tome opširnije: Zoran Grijak, „Korespondencija Šimun Milinović - Josip Juraj Strossmayer kao povijesni izvor", Zbornik Odsjeka za povijesne znanosti Zavoda za povijesne i društvene znanosti Hrvatske akademije znanosti i umjetnosti 36 (2018): 224.

36 Šuljak, „Biskup Josip Juraj Strossmayer i ćirilometodsko-glagoljska baština”, 288-289. 
nije spoznaje s tim u vezi. Naime, nije znao da je, u vrijeme kad je on 5. lipnja 1885. pun entuzijazma podržao Strossmayerov put u Moravsku na Velehradsku svečanost 5. srpnja, njegov otac već znao da su austrougarske vlasti onemogućile sudjelovanje biskupa Posilovića na toj svečanosti. Kosto Vojnović očito nije na vrijeme o tome obavijestio sina, a tiskovine su o cijeloj stvari donosile vrlo šture obavijesti. Čak su se i one pravaške, koje su zbog naznačenih načelnih političkih razloga podržavale zabranu hodočašća, suzdržale od bilo kakva slavodobitnoga komentara jer je zabrana putovanja hrvatskim crkvenim dostojanstvenicima koji su trebali predvoditi svečano misno slavlje u Velehradu ustvari bila očit dokaz tvrdnje Stranke prava o nesuverenosti hrvatskoga naroda u sklopu dualistički ustrojene Austro-Ugarske Monarhije. ${ }^{37}$ Kosto Vojnović bio je još u prvoj polovini svibnja upoznat $s$ tim da Posilović neće otputovati u Velehrad. Njegovo pismo Strossmayeru od 15. svibnja 1885. posvjedočuje da mu je tu vijest prenio Aleksandar Bresztyenszky, ${ }^{38}$ koji je to doznao iz Posilovićeva pisma. Kosto Vojnović

${ }_{37}$ U svojoj je privatnoj korespondenciji, međutim, prvak Stranke prava A. Starčević nakon zabrane odlaska hrvatskih katoličkih hodočasnika i dijela episkopata (biskupa Posilovića i Hranilovića) na Velehradsku proslavu 5. srpnja 1885. očitovao svoja negativna stajališta prema Velehradskoj proslavi i njezinim intencijama, koje je bez ostatka ocijenio političkim, na tragu svojih prijašnjih ocjena, iznijetih u pravaškoj Slobodi (br. 44/1885), da katolici u Hrvatskoj, Češkoj, Poljskoj i dr. nemaju mnogo zajedničkoga te da je Velehradska proslava ustvari politička demonstracija pod krinkom vjerozakona. To je napose vidljivo iz njegova pisma uglednom češkom novinaru i političaru Gustavu Eimu iz listopada 1885., u kojem je pak iznio nova stajališta o političkim intencijama hrvatskoga episkopata, koji je bio uključen u organizaciju hodočašća u Velehrad, ustvrdivši da je glavni uzrok nedolaska „vrijednijih ljudi i puka" na Velehradsku proslavu, koju su planirala tri hrvatska biskupa (Strossmayer, Posilović i Hranilović) i tri fakulteta zagrebačkoga sveučilišta (Pravni, Filozofski i Bogoslovni), taj što su oni shvatili da to ide u prilog Austriji. To pismo očito treba promatrati u kontekstu tadašnjih Starčevićevih afiniteta prema Rusiji, ali i kao dio njegova specifičnoga sarkazma, koji se ogledao u izrugivanju političkim protivnicima, u konkretnom slučaju trojici hrvatskih biskupa čiji se „proaustrijski” plan izjalovio. Starčević je međutim znao za austrijsku zabranu hodočašća te da nema ni govora o bilo kakvim proaustrijskim intencijama spomenutih biskupa u vezi s organiziranjem hodočašća u Velehrad. Može se pretpostaviti da je takvom interpretacijom, usto što je očito htio „ridikulizirati” krah planova hrvatskoga episkopata u vezi s organizacijom velehradskoga hodočašća, htio onemogućiti i da „neodvišnjaci” kod uglednih političara iz slavenskih zemalja Monarhije politički iskoriste ovaj očito represivan postupak austrijske vlade prema njima. Stoga ih je, unatoč posvemašnjemu nedostatku argumenata za spomenute tvrdnje, bez bilo kakva krzmanja tendenciozno prikazao kao „sluge Austrije”. Vidi: „A. Starčević - G. Eimu, Zagreb, 18. listopada 1885.”, u: Blaž Jurišić, prir., Ante Starčević. Izabrani spisi (Zagreb: Izdanje Hrvatskog izdavalačkog bibliografskog zavoda, 1943), 389-390.

38 Aleksandar Bresztyenszky (Prečec kod Dugog Sela, 6. rujna 1843. - Pleso, 9. svibnja 1904.). Gimnaziju je pohađao u Zagrebu, a pravo studirao u Zagrebu i Budimpešti, gdje je 1868. doktorirao. Iste godine postaje informator kod baruna Levina Raucha, istaknutoga predstavnika Narodne (mađaronske) stranke, bana od 1868. do 1871. Kao unionist preuzeo je katedru hrvatsko-ugarskoga privatnog prava na Pravoslovnoj akademiji (od 1874. Pravni fakultet Sveučilišta u Zagrebu). Godine 1869. postao je izvanredni, a 1873. redoviti profesor. Bio je gradski zastupnik u Zagrebu. Napustivši režimsku Narodnu stranku, prilazi opoziciji i zauzima se za sjedinjenje hrvatskih opozicijskih stranaka. Zbog toga je, po nalogu bana Khuen-Héderváryja, 1894. umirovljen. Kad su se 1903. ujedinile Stranka prava i Neodvisna narodna stranka i osnovana skupina pod nazivom Hrvatska opozicija, Bresztyensz- 
smatrao je da je za to odgovoran promađarski orijentiran zagrebački nadbiskup kardinal Josip Mihalović, ${ }^{39}$ kod kojega je Posilović tijekom svojega nedavnog boravka u Zagrebu bio gost. Neinformiran o svim relevantnim okolnostima Posilovićeva odustajanja od putovanja u Velehrad, držao je da ga je nadbiskup Mihalović uspio odgovoriti od te nakane te da se Posilović oportunistički priklonio intencijama ugarske, odnosno hrvatsko-slavonske vlade glede opstrukcije Velehradske proslave. Takvo stajalište popratio je riječima punim prijekora i ogorčenja, a njegova osuda Posilovićeva postupka bila je tim veća jer mu je ovaj osobno u razgovoru povjerio da je oduševljen idejom o hodočašću u Velehrad. ${ }^{40}$ U nastavku pisma K. Vojnović odaje priznanje Strossmayeru za njegovo veliko zauzimanje za organiziranje hrvatskoga hodočašća u Velehrad, a novonastalu situaciju ocjenjuje ponajprije kao posljedicu nepovoljnih crkveno-političkih prilika u kraljevinama Hrvatskoj i Slavoniji, gdje je lojalnost nositelja najviše političke i crkvene vlasti, bana Khuen-Héderváryja i zagrebačkoga nadbiskupa kardinala Mihalovića, bila usmjerena napose prema ugarskoj vladi, a Khuen-Héderváryja i prema austrijskoj vladi i političkim intencijama cara i kralja Franje Josipa I. u kraljevinama Hrvatskoj i Slavoniji. Iz pisma K. Vojnovića Strossmayeru može se zaključiti da je pretpostavljao da je Posilović bio izložen pritisku obojice, kao i s njima povezanih osoba: „I tako, moj Preuzvišeni, svi su po malo sudjelovali, da osujete taj actum fidei, ${ }^{41}$ na Metodijevu grobu. ${ }^{32} \mathrm{~S}$ obzirom na to da je izostan-

ky je postao predsjednikom njezina saborskoga kluba. Koaliciji se 1904. pridružila grupa naprednjaka iz razjedinjene Stranke prava te je ubrzo zatim iz tih skupina utemeljena Hrvatska stranka prava. Za predsjednika te nehomogene stranke izabran je Bresztyenszky, koji je poslije bio narodni zastupnik turopoljske općine u Saboru. Bio je istaknuti katolički laik. Podržavao je aktivnosti na planu sjedinjenja crkava vrhbosanskoga nadbiskupa Josipa Stadlera (kao urednik časopisa Balkan: jedinstvu $i$ bratskoj slogi, Zagreb, 1896. - 1902.) i biskupa Strossmayera. Vidi: Zdenko Šenoa, „Aleksandar Bresztyenszky”, u: Hrvatski biografski leksikon, sv. 2 (Zagreb: Leksikografski zavod „Miroslav Krleža”, 1989), 297.

39 Josip Mihalović (Torda, Banat, 16. siječnja 1814. - Zagreb, 19. veljače 1891.). Godine 1836. postao je svećenik u rodnoj Čanadskoj biskupiji. Bio je pristaša mađarske revolucije i sudionik revolucionarnih događaja u Temišvaru 1848. Kao politički osvjedočenoga Mađara, ugarski ministar predsjednik Gyula Andrássy i ministar bogoštovlja József Eötvös predložili su ga nakon smrti kardinala Jurja Haulika 1869. za zagrebačkoga nadbiskupa, zatajivši Franji Josipu I. njegovo protuaustrijsko i revolucionarno djelovanje u prošlosti. Car ga je 4. svibnja 1870. imenovao zagrebačkim nadbiskupom, a papa Pio IX. 1877. proglasio kardinalom. Hrvatski leksikon, sv. 2, gl. ur. Antun Vujić (Zagreb: Leksikografski zavod „Miroslav Krleža”, 1997), 100.

40 „Razočarani smo i u našoj najčednijoj želji. Posilović je pisô Breztyenskomu iz Senja, - da ne može slavensku misu u Velehradu pjevati, da si može domisliti za što [da može dokučiti zbog čega, op. a.], da drži to po mogućnosti tajno [...]. Kad sam ja zadnji put ovdje s njim o tome govorio, bio je oduševljen za tu misao. Slutim, da je bila nesreća, što je [...] dugo boravio [kao] gost, kako po običaju, kardinala. Lasno si možete misliti, koji su ga prionuli [tko je sve na njega izvršio pritisak, op. a.] [...]." HR-AHAZU, F/OJJS, Korespondencija, Pisma Strossmayeru (48), Kosta Vojnović (dalje: XI-A-48, Voj. Ko.), 154, Kosto Vojnović - J. J. Strossmayeru, Zagreb, 15. svibnja 1885.

${ }^{41}$ Lat. čin vjere.

${ }^{42}$ HR-AHAZU, F/OJJS, XI-A-48, Voj. Ko., 154, Kosto Vojnović - J. J. Strossmayeru, Zagreb, 15. svibnja 1885. 
kom senjsko-modruškoga biskupa Posilovića, koji je trebao predvoditi starocrkvenoslavensku misu u Velehradu, te nakon izricanja iste zabrane križevačkom grkokatoličkom biskupu Hraniloviću, izostao i glavni cilj odlaska hrvatskoga hodočašća na Velehradsku proslavu, K. Vojnović na kraju pisma savjetuje Strossmayeru neka se privatno uputi u Velehrad i slavljenjem mise na grobu sv. Metoda doprinese toj velikoj obljetnici ili da promisli o tome bi li bilo prikladno da se pridruži Slovencima. ${ }^{43}$ Naime, izostankom Posilovića i Hranilovića hrvatsko je hodočašće izgubilo svoju glavnu svrhu jer je misno slavlje u starocrkvenoslavenskom obredu trebalo biti kruna Velehradske proslave, javni čin afirmacije starocrkvenoslavenske liturgije kao krucijalnoga čimbenika crkvenoga sjedinjenja na masovnom crkvenom okupljanju katolika, grkokatolika i pravoslavaca bez presedana.

Iz navedenoga je sasvim jasno da K. Vojnović 15. svibnja 1885., u trenutku kad je Strossmayeru pisao spomenuto pismo, nije bio upućen u prave okolnosti zabrane Posilovićeva putovanja u Velehrad, naime da je Sveta Stolica na to pristala tek na zahtjev austrijskoga cara i hrvatsko-ugarskoga kralja Franje Josipa I., koji joj se $s$ tim u vezi osobno obratio. ${ }^{44}$ Očito je međutim da ne samo K. Vojnović nego ni Strossmayer i Rački nisu sredinom svibnja 1885. bili upućeni u to da je Posilovićev put u Velehrad onemogućen tek osobnom intervencijom cara Franje Josipa I. kod Svete Stolice jer su za opstrukciju Posilovićeva puta optuživali napose ugarsku i hrvatsko-slavonsku vladu. To je vidljivo iz pisma Račkoga Strossmayeru od 17. svibnja 1885., u kojem je Rački glede Posilovićeva odustajanja od puta u Velehrad te njegova odbijanja da otkrije tko mu je poslao pismo kojim mu se to zabranjuje, osuđujući Posilovićevo držanje ustvrdio da on ni u kojem slučaju ne bi popustio pritisku svjetovnih autoriteta jer je to izravno miješanje države u crkvene poslove, koje je čak usporedio s cezaropapizmom. ${ }^{45}$ Strossmayer u pismu od 29. lipnja

${ }^{43}$ HR-AHAZU, F/OJJS, XI-A-48, Voj. Ko., 154, Kosto Vojnović - J. J. Strossmayeru, Zagreb, 15. svibnja 1885.

${ }^{44} \mathrm{Na}$ tu činjenicu, koju napose potkrepljuje Strossmayerovo pismo nunciju Vannutelliju od 13. lipnja 1885., u kojem Strossmayer izričito spominje zabranu s „najvišega mjesta” putovanja u Velehrad Posiloviću i Hraniloviću, upozorio je A. Šuljak: „[...] sam car je preko Apostolskog nuncija zabranio senjskom biskupu-glagoljašu putovanje u Velehrad. I tako je velika obljetnica u Velehradu, odlukom politike i sile, umjesto sveslavenska i ćirilometodska, bila samo moravska i bez toliko željene staroslavenske mise.” Vidi: Šuljak, „Biskup Josip Juraj Strossmayer i ćirilometodsko-glagoljska baština”, 288. S tim u vezi treba svakako upozoriti na to da se radilo o intervenciji na koju se Sveta Stolica nije mogla oglušiti bez vrlo ozbiljnih posljedica za odnose s Austro-Ugarskom Monarhijom, koja joj je inače bila najvažniji politički oslonac u sučeljavanju s vladama pojedinih prema njoj neprijateljski raspoloženih država, napose Kraljevine Italije (vidi. bilj. 49).

${ }_{45}$ Rački je pritom ustvrdio da takvo upletanje u crkvene poslove kakvo je pripisivao Hrvatsko-slavonskoj zemaljskoj vladi i banu Khuen-Héderváryju, koji se nalazio na njezinu čelu, glede opstrukcije Posilovićeva puta u Velehrad ne postoji ni u Ruskom Carstvu: „Car je ruski u crkvenih nutarnjih poslovih mnogo pokorniji ruskoj svetoj sinodi i hijerarhiji.” Ne znajući za sve bitne momente kojima se pritom rukovodila Sveta Stolica, o kojima će biti više riječi u nastavku rada, Rački vrlo radikalno kritizira njezino postupanje prema katoličkim Slavenima i savjetuje Strossmayeru održavanje dobrih, 
1885. javlja Račkom da će tijekom boravka u Beču, gdje se namjerava susresti s nuncijem Vannutellijem i biskupom Posilovićem, otvoreno pitati Posilovića tko mu je zabranio odlazak u Velehrad. ${ }^{46}$ Glede rezultata te Strossmayerove nakane pretpostavljam da mu je Posilović uskratio odgovor. Međutim, iz Strossmayerova pisma Vannutelliju od 13. lipnja 1885., u kojem spominje intervenciju s „najvišega mjesta”, očito je da je u međuvremenu od nekoga - za koga je opravdano pretpostaviti da je bio blizak Rimskoj kuriji ili joj je čak pripadao kao član Kardinalskoga zbora ili rimskih kongregacija - s kim je bio u kontaktu doznao za intervenciju Franje Josipa I. kod Svete Stolice radi zabrane Posilovićeva putovanja u Velehrad. U pismu K. Vojnoviću od 22. lipnja 1885. Strossmayer, referirajući se na njegov savjet iznesen u pismu od 15. svibnja da sâm otputuje u Velehrad, javlja da je odlučio to učiniti, ali dvoji o tome da li da ondje održi misu 5. ili 8. srpnja. Naime, nije još odlučio bi li bilo prikladnije da održi misu u Đakovu na blagdan sv. Ćirila i Metoda 5. srpnja, a potom se uputi u Velehrad i ondje obavi

ali rezerviranih odnosa s njom i bečkim nuncijem „[...] kada oni u tolikoj mjeri tjeraju politiku oportuniteta”. Ferdo Šišić, prir., Korespondencija Rački-Strossmayer, knj. treća: od 5. jan. 1882. do 27. juna 1888. (Zagreb: Jugoslavenska akademija znanosti i umjetnosti, 1930), 177. Prigovor Račkoga da se kod upletanja državnih vlasti u Velehradsku proslavu 1885. radilo o cezaropapizmu, uzimajući u obzir i povijesno utvrđenu činjenicu da je odlazak biskupa Posilovića u Moravsku opstruiran osobnom intervencijom austrijskoga cara i hrvatsko-ugarskoga kralja Franje Josipa I., neosnovan je, napose jer starocrkvenoslavenska liturgija za vlasti Austro-Ugarske Monarhije ni u kojem slučaju nije bila samo vjerski fenomen, nego su ju, zbog prije naznačenih razloga, a napose stajališta da ona djeluje poticajno na širenje panslavizma i predstavlja opasnost za održanje Austro-Ugarske Monarhije, tretirale kao poglavito politički problem. To im je nedvojbeno pružalo dovoljno argumenata za intervenciju kod Svete Stolice. S druge strane nepobitno je da su opstrukciju Velehradske proslave austrougarskih vlasti slavenski katolički dostojanstvenici u Austro-Ugarskoj Monarhiji, napose hrvatski, čiji su predstavnici trebali predvoditi svečano misno slavlje na starocrkvenoslavenskom jeziku, shvatili isključivo kao jedan u nizu represivnih postupaka austrijskih Nijemaca i Mađara prema katoličkim Slavenima u sklopu Monarhije, a nadasve kao pokušaj zatiranja njihove obredne baštine, starocrkvenoslavenske liturgije, koja je ujedno bila važan segment njihova kulturnoga identiteta. Takav stav austrougarskih vlasti snažno ih je antagonizirao prema Austro-Ugarskoj Monarhiji, što najočitije dolazi do izražaja upravo u korespondenciji Račkoga i Strossmayera. To je pak pridonosilo pothranjivanju i gomilanju ionako već u znatnoj mjeri prisutnih protumonarhijskih antagonizama kod slavenskih nacija Monarhije, i to ne samo u crkvenoj nego i političkoj i javnoj sferi, što je u dugoročnom smislu, glede održanja Austro-Ugarske Monarhije, bilo znatno opasnije od panslavenske prijetnje, koje su se Beč i Budimpešta gotovo panično pribojavali, ne uviđajući da je najučinkovitiji način njezina preveniranja upravo udovoljavanje opravdanim nacionalnim težnjama Slavena u sklopu državnopravno preustrojene Monarhije. To se na kraju, doduše, i shvatilo, ali prekasno (Manifest cara i kralja Karla I. /IV./ o savezu slobodnih naroda, odnosno federalističkom preustroju Austro-Ugarske Monarhije od 16. listopada 1918.).

46 „Ja ostajem ovd do inclusive 5. jula. 8. odilazim u Beč, gdje bi se rad sastao s nuncijem, sa Helfertom [Alexander Helfert, austrijski publicist, tijekom 1880-ih zauzimao se za uspostavljanje trijalizma s neposrednom podčinjenošću hrvatskih i drugih južnoslavenskih zemalja austrijskoj vladi i sudjelovanje izabranih predstavnika hrvatskoga Sabora u bečkom Carevinskom vijeću, op. a.] i sa Posilovićem, koji će u isto doba biti otprilike u Beču putujući u Karlove Vari [češ. Karlovy Vary / njem. Karlsbad, svjetski poznato termalno lječilište u Češkoj, op. a.]. Rad bi iz njegovih samih ustiju čuo, tko mu je zabranio da misu pjeva staroslavenskim u Velehradu." Šišić, Korespondencija Rački-Strossmayer, 183. 
pobožnosti 8. srpnja ili da se uputi Moravsku ranije te 5. srpnja 1885. u Velehradu sudjeluje u slavljenju svečane mise u povodu 1000. obljetnice smrti sv. Metoda. Prva mogućnost činila mu se prikladnijom, ali nije o tome još zauzeo konačan stav. ${ }^{47}$ Međutim, u pismu od 26. lipnja 1885. Strossmayer javlja Vojnoviću da neće otputovati u Velehrad na proslavu 5. srpnja, a da mogućnost odlaska 6. srpnja ovisi o okolnostima. Kao uzrok odustajanja navodi da mu je Cesare Tondini, ${ }^{48}$ talijanski barnabit kojega je Sveta Stolica 1883. uputila u Kraljevinu Srbiju, na njegov poticaj, kao apostolskoga administratora za Srbiju (1851. - 1897.), javio da ga je državni tajnik Svete Stolice kardinal Lodovico Jacobini ${ }^{49}$ pozvao na razgovor, tijekom kojega mu je priopćio da mora napustiti Srbiju. ${ }^{50}$ Kao razlog donošenja te odluke rekao mu je da Austro-Ugarska Monarhija želi da napusti Srbiju, a da srpska vlada, premda nema ništa protiv njega, tu njezinu želju mora uvažiti jer ju na to obvezuju obziri prema njoj koji proizlaze iz Tajne konvencije iz $1881 .{ }^{51}$ Razlog

${ }^{47}$ HR - Nacionalna i sveučilišna knjižnica u Zagrebu - Zbirka rukopisa i starih knjiga, fond R 5622 b, Vojnović Kosta, Korespondencija (dalje: HR-NSK, ZRiSK, VKK, R 5622 b), J. J. Strossmayer - K. Vojnoviću, s. l., 22. VI. 1880. Istoga dana Strossmayer je tu vijest priopćio i Račkom. Vidi: Šišić, Korespondencija Rački-Strossmayer, 181.

${ }^{48}$ Cesare Tondini de'Quarenghi (Lodi, 11. siječnja 1839. - Rim, 29. lipnja 1907.). Godine 1862. primio je svećenički red i upućen je u barnabitski zavod u Parizu, a 1864. odlazi u Rusiju, koju je zbog širenja letka s molitvom za obraćenje Rusije ubrzo morao napustiti. Do 1867. djeluje u Kristianstadu u Švedskoj, a zatim opet u Parizu. Nakon Prvoga vatikanskog sabora objavio je raspravu pod naslovom The Pope of Rome and the Popes of the Oriental Orthodox Church: an essay on monarchy in the Church with special reference to Russia, from original documents, Russian and Greek (London: Longmans, Green and Co., 1871). Godine 1883. Sveta Stolica uputila ga je u misiju u Kragujevac, odakle 1885. prelazi u Niš zbog pastoralnih potreba katoličkih radnika na željeznici. Zatim se vratio u Kragujevac, a u Nišu je ostao reformirani poljski benediktinac (kamaldolijanac) Willibald Czock. Kad je Tondini počeo poticati srpsku vladu na sklapanje konkordata sa Svetom Stolicom, austrougarska diplomacija zatražila je od Svete Stolice njegovo uklanjanje iz Srbije. Po povratku u Rim sudjeluje u pregovorima o crnogorskom konkordatu (1886.) i objavljuje djelo La Russia e l'unione delle chiese (Rim: Forzani e Cia., tipografi del Senato, 1895). Vidi: Rita Tolomeo, Korespondencija Josip Juraj Strossmayer - Cesare Tondini de'Quarenghi (Zagreb: Arhiv Hrvatske, 1984); Monica Priante, Slavko Slišković, Tondini i Strossmayer. Jedinstveni za jedinstvo (Zagreb: Kršćanska sadašnjost, 2016).

49 Lodovico Jacobini (Genzano, 6. siječnja 1832. - Rim, 27. veljače 1887.). Bio je apostolski nuncij u Beču (1874. - 1879.) kad ga je papa Lav XIII. proglasio kardinalom, a u prosincu 1880. imenovao državnim tajnikom. Godine 1879. dao je inicijativu za obnovu odnosa između Svete Stolice i Njemačkoga Carstva nakon svršetka Kulturkampfa (1871. - 1879.). Tijekom prvih mjeseci svojega pontifikata papa Lav XIII. (1878. - 1903.) preko njega je zatražio austrijsku pomoć u obuzdavanju rastućega neprijateljstva Kraljevine Italije protiv Svete Stolice, koje nije jenjavalo od njezina osnutka 1870. Vidi: Donato Squicciarini, Nunzi Apostolici a Vienna (Città del Vaticano: Libreria Editrice Vaticana, 1998), 222-224.

${ }^{50}$ HR-NSK, ZRiSK, VKK, R 5622 b, J. J. Strossmayer - K. Vojnoviću, [Đakovo], 26. VI. 1885. Identične informacije Strossmayer je prenio Račkom 29. lipnja 1885. Šišić, Korespondencija Rački-Strossmayer, 183.

51 „U hitnji samo dvie rieči. Ja neidem 5. Jula u Velehrad, jer se osobite njeke stvari dogadjaju u Srbiji. Piše mi naime Tondini, da mu General [vrhovni poglavar barnabitskoga reda, op. a.] iz Rima piše da ga je Staats sekretar [der Staatssekretär (njem.), državni tajnik, op. a.] Jakobini k sebi zvati dao, i da mu je rekao: da Tondini mora odmah iz Serbije, jer da ga Austro-Ugarska, a osobito pako Ugarska, 
zbog kojega je Austro-Ugarska Monarhija zatražila od srpske vlade uklanjanje Tondinija iz Kraljevine Srbije bilo je, kako je već naznačeno, njegovo zauzimanje za sklapanje konkordata između Svete Stolice i Kraljevine Srbije, a kao neposredan povod iskorišten je njegov memorandum za utemeljenje katoličke biskupije u Kraljevini Srbiji, ${ }^{52}$ u čemu je Austro-Ugarska Monarhija prepoznala veliku opasnost jer bi se u tom slučaju znatno osnažile srpske pozicije kao mogućega centra južnoslavenskoga okupljanja za katoličke Slavene u Monarhiji, a ujedno bi se pružio poticaj ruskim ambicijama za penetraciju na Balkan i topla mora, što bi u bitnom smislu bila prijetnja za jugoistočnu granicu Austro-Ugarske Monarhije i samo njezino održanje. Zato je ugledni bečki dnevnik Wiener Allgemeine Zeitung objavio službeno priopćenje kojim se u cijelosti demantira bilo kakva nakana kralja Milana Obrenovića da podrži sklapanje konkordata između Kraljevine Srbije i Svete Stolice, u čemu je, prema navodima priopćenja, trebao posredovati biskup Strossmayer, a odgovornost za imputiranje takve nakane kralju Milanu pripisuje se južnoslavenskim huškačkim tiskovinama, za koje se tvrdi da im je cilj bio umanjiti ugled kralja Milana kod pravoslavnih Srba. ${ }^{53}$

u Serbiji netrpi. Kazô, da je dugo vriemena branio Tondinia, ali, da je naposlietku popustio, osobito kad mu je Nuntius iz Beča pisao, da je kralj sam Serbie [Milan Obrenović, vladao Srbijom od 1868. do 1889., najprije kao knez, a od 1882. kao kralj, op. a.] bio kod Nuntiusa, i pripoviedao mu: kako priznati mora, da je otac Tondini dobar, učen, revan svećenik i kako on sam i Serbia ništ prot njemu neima, ali buduć je Austro-Ugarska Vlada, osobito Ugarska prot njemu i buduć, da on u svemu želi zadovoljiti Austro-Ugarsku [...], to on mora moliti i zahtievati, da se otac Tondini odmah opozove iz Serbie. [...] Ja dakle ostajem još njeko vrieme kod kuće i obaviti ću i Petrovo i 5. Jul ovd [blagdan sv. Petra i Pavla ap. 29. lipnja i blagdan sv. Ćirila i Metoda 5. srpnja, op. a.], hoćul' pako 6. Jula odputovati u Velehrad [...] to visi o okolnosti." HR-NSK, ZRiSK, VKK, R 5622 b, J. J. Strossmayer - K. Vojnoviću, [Đakovo], 26. VI. 1885. Tajna konvencija od 28. lipnja 1881. ugovor je između Austro-Ugarske Monarhije i Kneževine Srbije o napuštanju srpske proruske orijentacije i uvođenju proaustrijskoga smjera. Tim ugovorom Austro-Ugarska Monarhija obvezala se podržati proglašenje Kneževine Srbije kraljevinom (1882.), a Kneževina Srbija da neće sklapati nikakve političke saveze bez prethodnoga sporazuma s Austro-Ugarskom Monarhijom. U slučaju proglašenja rata protiv jedne od potpisnica ugovora, obje strane obvezuju se na neutralnost. Ugovor, koji je sadržavao i niz drugih važnih odredaba, bio je najprije zaključen na 10 godina te je bio produžen do 1 . siječnja 1895., kad je sporazum istekao. Vidi opširnije: Grgur Jakšić, Iz novije srpske istorije. Abdikacija kralja Milana i druge rasprave (Beograd: Prosveta, 1953), 80-81.

52 Tondini je 25. travnja 1885. uručio srpskom kralju Milanu Obrenoviću memorandum naslovljen Mémoire sur la situation de l'Eglise catholique en Serbie, u kojem je iznio plan nove organizacije Katoličke crkve u Srbiji. Prema tom bi planu u Srbiji bila uspostavljena samostalna biskupija. Premda je Tondini zahtijevao tajnost toga dokumenta, kralj Milan predočio ga je austrijskom poslaniku Rudolfu Khevenhülleru, koji ga je odmah zatim proslijedio u Beč ministru vanjskih poslova Austro-Ugarske Monarhije Gustavu Kálnokyju, koji je o tome obavijestio bečkoga nuncija Vannutellija, a on je s tim upoznao papu Lava XIII. U srpnju 1885. Tondini je zbog energične austrougarske intervencije kod srpske vlade, u atmosferi intrige i skandala, morao napustiti Srbiju. Piotr Żurek, „Razlozi ostavke biskupa Josipa Juraja Strossmayera na položaj apostolskog administratora Katoličke crkve u Srbiji”, Časopis za suvremenu povijest 34 (2002), br. 3: 786-787.

53 „Die in verschiedenen Blättern aufgetauchte Nachricht, daß König Milan mit der römisch-katholischen Kirche eine Union eingehen wolle und das Bischof Strossmayer der Vermittler sei, wird von zuständigster Seite in ihrem ganzen Umfange auf das bestimmteste bestritten mit dem Beifügen, daß 
S obzirom na nadasve kompleksnu političku situaciju u vezi s okolnostima uklanjanja Tondinija iz Kraljevine Srbije, Strossmayer je držao vrlo rizičnim otputovati u Velehrad jer mu je u odsutnosti moglo promaknuti nešto krucijalno za budući slijed događaja. Austrougarske su vlasti Strossmayerov odlazak u Velehrad također mogle iskoristiti za ugrožavanje njegove pozicije kao apostolskoga vikara za Srbiju, povezujući akciju za uklanjanje Tondinija s pokušajem uklanjanja njega osobno s toga položaja pod izlikom da kao inicijator velehradskoga hodočašća $s$ hrvatske strane sudjeluje u panslavenskoj političkoj manifestaciji pod krinkom religije usmjerenoj protiv interesa održanja Austro-Ugarske Monarhije. Usto mu se moglo imputirati, na što je aludirao spomenuti članak u Wiener Allgemeine Zeitungu, da je trebao biti posrednik u sklapanju konkordata između Kraljevine Srbije i Svete Stolice, što je uvelike povećavalo rizik njegova odlaska u Velehrad. Na bilo kakvu promjenu držanja Svete Stolice glede mogućnosti sudjelovanja hrvatskog episkopata u slavljenju središnje svečane mise na starocrkvenoslavenskom jeziku u Velehradu 5. srpnja 1885. nije mogla nimalo utjecati ni činjenica da je inače odlučila u čast sv. Ćirila i Metoda u Rimu održati svečane mise u bazilici San Clemente 3., 4. i 5. srpnja $1885 .{ }^{54}$ jer je s tim u vezi već bila učinila ustupak Austro-Ugarskoj Monarhiji zabranivši putovanje biskupima Posiloviću i Hraniloviću, koji su u Velehradu trebali slaviti starocrkvenoslavensku misu. Time je, u stvari, kako je već napomenuto, i samo hodočašće postalo bespredmetno jer misa na starocrkvenoslavenskom jeziku nije imala samo simboličnu ulogu uveličavanja svečanosti nego i zadatak afirmacije katoličkih Slavena u sklopu Katoličke crkve i starocrkvenoslavenske liturgije kao krucijalnoga elementa crkvenoga povezivanja. Pritom neizostavno treba upozoriti na to da je u vrijeme protjerivanja Tondinija iz Srbije 1885. zbog poticanja pregovora o konkordatu sa srpskom vladom i uručivanja istoj memoranduma o utemeljenju katoličke biskupije u Kraljevini Srbiji, što je Austro-Ugarska Monarhija ocijenila iznimno opasnim iz navedenih razloga, Sveta Stolica vodila pregovore o konkordatu s vladom Kneževine Crne Gore, koji je uspješno realiziran $1886 .{ }^{55}$ To je svakako bio moment koji je

diese Nachricht aus südslawischen Hetzblättern stamme, welche beabsichtigen, König Milan bei dem orthodoxen Serben mißliebig zu machen.” „Wien, 30. Juni 1885. Zur Situation”, Wiener Allgemeine Zeitung. Morgenblatt (Wien), Nr. 1915, 1. Juli 1885, 3, Österreichische Nationalbibliothek, ANNO Historische österreichische Zeitungen und Zeitschriften, pristup ostvaren 15. 6. 2021., https://anno. onb.ac.at/cgi-content/anno?aid=waz\&datum $=18850701 \&$ seite $=3 \&$ zoom $=33$. Napomena: zbog ograničenih opsegovnih okvira članka neće se navoditi poveznica (https://anno.onb.ac.at/) pri svakom idućem referiranju na članke iz te tiskovine. To se odnosi i na bečki dnevnik Neue Freie Presse, koji ima istu poveznicu, a koji će se također višekratno citirati u nastavku rada. Svi pristupi tim tiskovinama ostvareni su od 15. do 29. lipnja 2021.

54 Strossmayer je o tome obavijestio Račkoga u pismu od 22. lipnja 1885.: „Sveti Otac je naredio da se 3., 4. i 5. jula u baziliki San Clemente sollennissimum triduum [lat. najsvečanije trodnevlje, aluzija na uskrsno (vazmeno) trodnevlje op. a.] obdržava na čast i poštenje svetih slavenskih apostola Cirila i Metoda. Ovo o triduumu dobro bi bilo uvrstiti u 'Pozor'.” Šišić, Korespondencija Rački-Strossmayer, 181.

${ }_{55}$ Vidi o tome opširnije: Ivan Jakulj, „Međunarodni ugovori Svete Stolice i Crne Gore: Povijesno-pravni vid", Crkva u svijetu 48 (2013), br. 2: 236-261. Crnogorski konkordat (1886.) - koji je Sveta 
Svetu Stolicu dodatno upućivao na oprez i sklonost ustupcima Austro-Ugarskoj Monarhiji glede Velehradske proslave, što se očitovalo i u njezinu pristanku na zahtjev Franje Josipa I. da zabrani put u Velehrad biskupu Posiloviću, a potom i Hraniloviću, jer ni pod koju cijenu nije htjela izazvati Austro-Ugarsku Monarhiju na otvoreno negativnu reakciju glede crnogorskoga konkordata s obzirom na to da je Austro-Ugarska Monarhija bila i protiv toga konkordata, ali nije raspolagala diplomatskim sredstvima kojima bi ga spriječila kao u slučaju Kraljevine Srbije, pozivajući se na Tajnu konvenciju iz 1881. Naime, Austro-Ugarska Monarhija smatrala je Kneževinu Crnu Goru potencijalno neprijateljskom državom zbog njezinih aspiracija prema širenju na Balkan, Boku kotorsku i južnu Dalmaciju te mogućnosti otvaranja puta za prodor Ruskoga Carstva, pod čijim se izrazitim političkim i ekonomskim utjecajem nalazila, na Balkan i topla mora. ${ }^{56}$

U daljnjem razmatranju nastojanja austrougarskih vlasti da opstruiraju Velehradsku proslavu svakako treba upozoriti na proglašenje epidemije u Moravskoj kao čin kojim je Austro-Ugarska Monarhija definitivno onemogućila realizaciju hrvatskoga, kao i slovenskoga, hodočašća u Velehrad, što je inače krucijalan istraživački segment ovoga rada. $S$ tim u vezi treba naglasiti da se vijesti o tome u Strossmayerovoj korespondenciji javljaju vrlo kasno, samo tjedan dana uoči Velehradske proslave. To međutim ne iznenađuje jer je, s obzirom na to da se nije radilo o stvarnoj nego izmišljenoj epidemiji, termin obznanjivanja te vijesti morao neposredno prethoditi hodočašću da se ne bi otvorila mogućnost za javno razotkrivanje obmane prije samoga održavanja proslave. Pritom je u vezi s proglašenjem epidemije u Moravskoj očito da austrougarske vlasti sve do uoči održavanja Velehradske proslave nisu bile sasvim sigurne u to hoće li se hrvatski episkopat odlučiti za organiziranje hodočašća unatoč zabrani putovanja u Velehrad senjskom-modruškom biskupu Posiloviću i križevačkom biskupu Hraniloviću, koji su jedini od hrvatskih katoličkih biskupa imali crkvene ovlasti i realno mogli, kao poznavatelji liturgijske tradicije i dionici obredne prakse, slaviti misno slavlje u starocrkvenoslavenskom obredu. Strossmayer prvi put spominje zabranu putovanja u Moravsku zbog proglašenja epidemije na njezinu teritoriju u svojem pismu Račkom od 29. lipnja 1885. Pritom iznosi ironične aluzije glede vjerodostojnosti same vijesti o epidemiji, što svjedoči da je znao da se radi o poli-

Stolica smatrala zamašnjakom za sklapanje konkordata s ostalim pravoslavnim državama, uključujući Rusiju, a ustvari je bio jedini koji je uspjela sklopiti u 19. stoljeću - najviši nositelji crnogorskih vlasti s vremenom su grubo izigrali i ignorirali, uvelike i pod utjecajem Ruskoga Carstva, koje je, napose preko svojih diplomatskih predstavnika, nastojalo odvratiti druge balkanske države da se povedu za crnogorskim primjerom. Činjenica da je Austro-Ugarska Monarhija također opstruirala konkordatsku politiku Svete Stolice na Balkanu učinila je neznatnom bilo kakvu mogućnost njezine realizacije. Gotovo je suvišno reći da je Austro-Ugarska Monarhija, kratkovidno držeći da time onemogućava ruska panslavistička nastojanja, ustvari u dugoročnom smislu krčila put ruskoj penetraciji na Balkan i topla mora. Vidi: Grijak, „Korespondencija Šimun Milinović - Josip Juraj Strossmayer kao povijesni izvor", 247-253.

56 Grijak, „Korespondencija Šimun Milinović - Josip Juraj Strossmayer kao povijesni izvor”, 215-255. 
tički motiviranoj obmani austrougarskih vlasti: „Što se međutim Velehrada tiče, vlada zabranjuje - kako znate - hodočasnikom putovati u Velehrad, jer se očinski brine za zdravlje i čistu kožu hodočasnika [podcrtao a.]." ${ }^{\text {7 }}$

Strossmayer je razvio iznimno dobre i vrlo povjerljive odnose s bečkim nuncijem Vannutellijem, s kojim je među ostalim korespondirao i o pitanju opstruiranja Velehradske proslave od strane austrougarskih vlasti. Premda su sve austrougarske inicijative kod Svete Stolice koje su se odnosile na hrvatske zemlje, uključujući i ovu, hrvatskom episkopatu posredovane preko Bečke nuncijature, Strossmayer ni u jednom trenutku nije našao razloge za prigovor s tim u vezi Vannutelliju jer je znao da je on osobno, premda je inače bio izrazito proaustrijski orijentiran, iznimno naklonjen svim akcijama hrvatskoga episkopata glede sjedinjenja crkava, kojih je važan segment bila i Velehradska proslava. Najodgovornijima za zabranu hrvatskoga hodočašća Strossmayer je, u svojem pismu Vannutelliju od 13. lipnja 1885., ocijenio ugarsku i hrvatsko-slavonsku vladu, što je inače vrlo začuđujuće jer upravo to pismo posvjedočuje da je u međuvremenu bio doznao za intervenciju Franje Josipa I. kod pape Lava XIII. kojom je osujećeno putovanje Posilovića i Hranilovića u Velehrad. Objašnjenje za Strossmayerovo isključivo označivanje odgovornima ugarske i hrvatsko-slavonske vlade, premda je već bio doznao da se radilo o intervenciji s „najvišega mjesta”, nalazi se u činjenici da je Strossmayer Mađare, prema kojima je i inače gajio izniman animozitet, držao najodgovornijima za tešku političku sudbinu hrvatskih zemalja nakon sklapanja Hrvatsko-ugarske nagodbe (1868.), a napose za nesuverenost hrvatskih političkih i crkvenih čimbenika u odlučivanju o najvažnijim političkim, financijskim i crkvenim pitanjima Trojedne Kraljevine. Stoga je sasvim očito da je taj događaj dovodio u najužu uzročno-posljedičnu vezu sa stanjem uspostavljenim Hrvatsko-ugarskom nagodbom, kojemu je pridavao primarnu, a intervenciji Franje Josipa I. tek sekundarnu, posljedičnu važnost. S tim u vezi Strossmayer je Vannutelliju 13. lipnja 1885. napisao: „Sad još nešto o našem svetom hodočašću u Velehrad u Moravskoj. [...] U nas ovdje na jugu prvenstveno dva razloga cijelu su stvar upropastila. Prvo, neprijateljstvo i otvoreni progon od strane ugarsko-hrvatske vlade. Kažu da je dvojici naših domaćih biskupa s najvišeg mjesta izrijekom bilo zabranjeno da sudjeluju u svetom hodočašću [ova rečenica sasvim nedvosmisleno upućuje na zaključak da je znao za intervenciju Franje Josipa I. kod Svete Stolice, op. a.] [...]. Nama Slavenima na jugu koji se dičimo katoličkim imenom pri ruci je cjelokupna baština svetih naših apostola Ćirila i Metodija. Pri ruci su nam dva katolička obreda; u oba obreda pri ruci nam je isti staroslavenski jezik. [...] Mi bismo se, dakle, barem tada u Velehradu, u skladu s našom naravi i našim vječnim predodređenjem, pojavili tako, da grčko-sjedinjeni biskup Hranilović grko-istočnim [bizantsko-slavenskim, op. a.], a senjski biskup latinskim

57 Strossmayer - Račkomu, [Đakovo], 29. juna 1885., u: Šišić, Korespondencija Rački-Strossmayer, 183. 
obredom [rimsko-slavenskim, op. a], svečano i ujedno obojica na staroslavenskom jeziku u Velehradu službu imaju; ali upravo je to potezom više vlasti kao panslavistički zločin najstrože zabranjeno." ${ }^{58}$

Strossmayerovu nakanu da sâm otputuje u Velehrad možemo pratiti više od mjesec dana nakon krajnjega roka, 6. srpnja, koji je najavio u pismu K. Vojnoviću 22. lipnja 1885. U međuvremenu se dogodila afera u vezi s uklanjanjem Tondinija iz Kraljevine Srbije, a zatim je uvedena zabrana hodočašća u Moravsku zbog proglašenja epidemije u okolici Velehrada, o čemu nalazimo podatke u njegovu pismu Račkom od 29. lipnja 1885. No Strossmayer se očito i dalje bavio mišlju da onamo otputuje sâm. Na najavu njegova kasnijega odlaska, o kojem ne nalazimo vjerodostojne podatke ni u kojem drugom dostupnom izvoru, K. Vojnović osvrnuo se u pismu od 10. kolovoza 1885.: „Preporučite ovu jadnu zemlju u Velehradu svetim našim Apoštolom. Neka Vas ovi čuvaju i štite, da možemo još u koga uprieti oči 'in hac lacrymarum valle." ${ }^{59}$ To je jedini izvor koji mi je bio dostupan, a pretpostavljam i posljednji, u kojem se spominje Strossmayerova nerealizirana nakana da se uputi u Velehrad više od mjesec dana nakon održavanja središnje Velehradske proslave 5. srpnja 1885.

U zaključku ovoga dijela rada može se ustvrditi da je hrvatsko hodočašće u Velehrad 1885. u povodu 1000. obljetnice smrti sv. Metoda bilo onemogućeno zbog zajedničkoga opstruiranja Velehradske proslave od Austro-Ugarske Monarhije, koja je uspjela za to ishoditi potporu Svete Stolice, i Ruskoga Carstva, koje je o tome postiglo sporazum s Austro-Ugarskom Monarhijom. Razlozi zbog kojih su Austro-Ugarska Monarhija i Rusko Carstvo napose središnju Velehradsku proslavu 5. srpnja 1885. smatrali prijetnjom za svoje vitalne političke interese detaljno su razmotreni te ih ovdje nije potrebno dodatno objašnjavati. S obzirom na temu ovoga članka posebno je važna činjenica da su austrougarske vlasti, kako bi otklonile svaku mogućnost velikoga hodočašća katoličkih Slavena u Velehrad, osobito Hrvata i Slovenaca, ne samo zabranile putovanje u Moravsku biskupima Posiloviću i Hraniloviću, koji su u Velehradu trebali slaviti svečanu misu u starocrkvenoslavenskom obredu, nego su u prethodnom dogovoru s ruskom vladom razglasile lažnu vijest o epidemiji te zatvorile pristup Moravskoj is austrijske is ruske strane.

Ako se uzmu u obzir najvažnije činjenice vezane uz opstrukciju Velehradske proslave iznijete u ovom radu, analizirane i potkrijepljene relevantnim izvorima - da je najprije intervencijom austrijskoga cara i hrvatsko-ugarskoga kralja Franje Josipa I. zabranjen put u Velehrad biskupima senjsko-modruškom Jurju Posiloviću i križevačkom Iliji Hraniloviću, a da su zatim radi potpunoga onemogućivanja

\footnotetext{
58 J. J. Strossmayer - S. Vannutelliju, Đakovo, 13. VI. 1885., u: Balabanić, Kolanović, Korespondencija Josip Juraj Strossmayer - Serafin Vannutelli, 481-483.

59 Lat. In hac lacrimarum valle, u ovoj suznoj dolini. HR-AHAZU, F/OJJS, XI-A-48, Voj. Ko., 166, K. Vojnović - J. J. Strossmayeru, Zagreb, Na Lovrinčevo [10. VIII.] 1885.
} 
dolaska hodočasnika iz drugih dijelova Austro-Ugarske Monarhije u Moravsku, napose Hrvata i Slovenaca te grkokatolika i pravoslavaca iz Ruskoga Carstva, austrougarske političke vlasti razglasile epidemiju u okolici Velehrada te zatvorile granicu prema Rusiji - začuđuju tvrdnje s tim u vezi inače za tu problematiku vrlo kompetentnoga slovačkog povjesničara Luboslava Hromjáka. On je naime, uopće ne spominjući austrougarsku opstrukciju Velehradske proslave, ustvrdio da je Posilović sudjelovao u velehradskom hodočašću s vjernicima iz svoje biskupije 14. srpnja 1885. i da je potom 27. rujna, kao i vođa „katoličkoga slavizma” Strossmayer, dobio dopuštenje za slavljenje svete mise u Velehradu. Jedino dvoji o tome je li održana misa na slavenskom jeziku, što se vjerojatno odnosi na rimsko-slavensku liturgiju koju je trebao predvoditi biskup Posilović. Za Hranilovića je naime sa sigurnošću ustvrdio da je slavio misu u starocrkvenoslavenskom obredu (bizantsko/grčko-slavenskom).$^{60}$ Držim da su iznesene tvrdnje u osnovi posljedica nekritičkoga preuzimanja neutemeljenih i netočnih tvrdnji iz djela autora u kojega se Hromják očito pouzdavao ${ }^{61}$ te ih stoga nije provjeravao tako da ih usporedi s podacima u relevantnim izvorima, što je inače u citiranom radu gotovo redovito činio, temeljeći svoje tvrdnje poglavito na arhivskom gradivu Apostolske nuncijature u Beču, pohranjenom u Tajnom vatikanskom arhivu (od 2019. Vatikanski apostolski arhiv, op. a.).

U nastavku rada razmotrit će se okolnosti proglašenja lažne epidemije u Moravskoj 1885., poglavito na temelju informacija iz dviju uglednih bečkih tiskovina, Neue Freie Pressea i Wiener Allgemeine Zeitunga. Treba reći da su ti listovi inače vrlo detaljno i objektivno izvješćivali o protuepidemijskim mjerama koje je $\mathrm{Au}$ stro-Ugarska Monarhija provodila u cilju zaštite od proširenja kolere, koja je posebice zahvatila Španjolsku, na svoj teritorij, a vrlo tendenciozno o pojavi navodnih infektivnih bolesti u Velehradu i njegovoj okolici. Naznačena diskrepancija jedna je od tema koje će se detaljnije analizirati u sljedećem poglavlju.

\footnotetext{
60 „An der Wallfahrt nahmen der Bischof aus Modrus und Senj Posilović mit ihren Treuen am 14. Juli 1885 teil und am 27. September 1885 erhielten sie, wie auch der Führer des katholischen Slawismus Josip Juraj Strossmayer, eine Erlaubnis für die Feier der heilige Messe in Velehrad. Es ist aber nicht sicher, ob die Heilige Messe in der slawischen Sprache gefeiert wurde. Was sicher ist, ist dass der griechisch-katholische Bischof Ilija Hranilović aus Križevec die Heilige Messe in altkirchenslawischer Sprache feierte.” Luboslav Hromják, „Josip Juraj Strossmayer und der katholische Slawismus aus slowakischer Perspektive”, u: Josip Juraj Strossmayer 1815-2015, Wien, 21. Mai 2015 - Roma, 9 dicembre 2015, ur. Darija Damjanović, Grgo Grbešić i Tomislav Mrkonjić (Đakovo: Katolički bogoslovni fakultet u Đakovu Sveučilišta Josipa Jurja Strossmayera u Osijeku, 2017), 175.
}

${ }^{61}$ Hromják, „Josip Juraj Strossmayer”, 175, bilj. 88. 


\section{Proglašenje u povijesti medicine nezabilježene epidemije na području Velehrada 1885. Zloporaba medicine u političke svrhe na primjeru uvođenja mjere zabrane kretanja}

Posebice velik problem za elaboraciju teme ovoga poglavlja nepostojanje je vjerodostojnih medicinskih izvora za oblikovanje spoznaja o navodnoj pojavi infektivnih bolesti u okolici Velehrada u Moravskoj 1885. godine. Kako je napomenuto, epidemiju u okolici Velehrada 1885. nisu službeno medicinski potvrdile tadašnje moravske javnozdravstvene zemaljske institucije nadležne za teritorij Velehrada, a nije registrirana ni u relevantnim medicinskim publikacijama. Tako ju, važno je upozoriti, ne nalazimo zabilježenu ni u zagrebačkom Liečničkom viestniku iz 1885., koji inače vrlo detaljno prenosi vijesti o snažnoj epidemiji kolere u Španjolskoj iste godine, tijekom koje je umrlo više od 80 tisuća ljudi, koja je započela u lipnju, a počela jenjavati tek u kolovozu, dakle koincidirala je s navodnom epidemijom u Velehradu. ${ }^{62} \mathrm{Ni}$ u pregledu svih ostalih infektivnih bolesti u Kraljevinama Hrvatskoj i Slavoniji, drugim dijelovima Europe i šire, na svjetskoj razini (boginje, trbušni tifus, šarlah i dr.), u Liečničkom viestniku ne nalazimo nikakve podatke za Moravsku. Sasvim je isključeno da bi taj ugledni medicinski časopis propustio registrirati pojavu bilo koje ozbiljnije infektivne bolesti u Moravskoj u naznačenom razdoblju, napose s obzirom na to da se radilo o području Austro-Ugarske Monarhije, u čijem su se sklopu u to vrijeme nalazile i Moravska i Trojedna Kraljevina, pa bi bilo kakva epidemija u njezinu okviru zasigurno naišla na posebnu pozornost. Još je manja, ustvari potpuno isključena, mogućnost da bi Odbor za proslavu Velehradske svečanosti 15. kolovoza 1885. uputio Liječničkom zboru Kraljevina Hrvatske i Slavonije poziv na sudjelovanje u Velehradskoj proslavi (koja je trajala i u kolovozu i rujnu) da su vijesti o bilo kakvoj pojavi epidemije bile vjerodostojne. ${ }^{63}$ Mogućnost takva previda treba sasvim otkloniti i zato što je medicina, osobito mikrobiologija kao temelj znanstvenoga utvrđivanja infektivnih bolesti, bila već na toliko visokom stupnju razvoja da se nijedna veća epidemija medicinski utvrđenih i registriranih bolesti - posebice $u$ zemljama s razvijenim javnozdravstvenim sustavom, koje su uspostavile trajni sustav protuepidemijske zaštite, a Austro-Ugarska Monarhija ubrajala se među njih - ni na koji način nije mogla previdjeti. Činjenica da je trajna protuepide-

\footnotetext{
62 „Kolera u Španjolskoj dohvatila je vrhunac prama koncu kolovoza o. g. [...] Pošto je već duže vremena bilo pojedinih, sporadičnih slučajeva, poprimila je kolera mjeseca lipnja očiti značaj pošasti. Toga mjeseca umrlo je 6.000 ljudi. U srpnju razširila se pošast po svoj zemlji, te je još više harala, 25.000 ljudi umrlo je od nje. A mjeseca kolovoza bila je [...] najžešća, te je onda naglo popustila. Toga mjeseca umrlo je svega 50.000 ljudi. Španija izgubila je dakle ovom pošasti kroz tri mjeseca preko 80.000 stanovnika." Liečnički viestnik: organ Sbora liečnika kraljevina Hrvatske i Slavonije (Zagreb), 7 (1885), br. 7: 119.

${ }^{63}$ „Dr. Hubert H. Krasinski u Krakovi poslao je našem sboru nekoliko svojih higijenskih radnja, a odbor za svečanost velehradsku u Moravskoj poziv na sudjelovanje.” Liečnički viestnik: organ Sbora liečnika kraljevina Hrvatske i Slavonije, 7 (1885), br. 5: 80.
} 
mijska zaštita u Habsburškoj Monarhiji uspostavljena stotinjak godina prije, ${ }^{64} \mathrm{uz}$ već iznesen podatak da o epidemiji u Moravskoj 1885. ne postoji nikakva potvrda za to mjerodavnih zemaljskih javnozdravstvenih tijela niti bilo kakva vijest $\mathrm{u}$ relevantnim suvremenim medicinskim publikacijama unatoč vrlo dinamičnom razvoju mikrobiologije u tom razdoblju, što je sasvim isključivalo njezin previd, pruža vrlo solidnu osnovu za zaključak da se u konkretnom slučaju uopće nije radilo o epidemiji, nego o ad hoc mjeri političke naravi s ciljem onemogućivanja kretanja hodočasnika, napose iz hrvatskih zemalja, prema Moravskoj. Takav zaključak u cijelosti potkrepljuje priopćenje s izvanredne sjednice Moravskoga zdravstvenog vijeća od 3. srpnja 1885., u kojem se konstatira da ne postoje razlozi za zabranu hodočašća u Velehrad iz zdravstveno-epidemioloških razloga ${ }^{65}$ To priopćenje, o kojemu će biti riječi i u nastavku rada, ujedno nepobitno svjedoči da se radilo o zloporabi medicine u političke svrhe od najviših organa političke vlasti Austro-Ugarske Monarhije, u odnosu na koje je Moravsko zdravstveno vijeće pokazalo iznimno visok stupanj autonomije. To je, valja upozoriti, krucijalni izvor koji sasvim nepobitno razotkriva političku manipulaciju i zloporabu medicine u konkretnom slučaju, što je istraživačka okosnica ovoga članka. Također se radi o jednom od najranijih svjedočanstava o uvođenju represivne mjere zabrane odnosno ograničenja kretanja u sklopu proglašenih epidemioloških mjera.

U nastavku rada najprije će se obratiti pozornost na aktualne mjere koje su austrougarske vlasti provodile radi sprječavanja širenja kolere na njezin teritorij $\mathrm{u}$ vrijeme Velehradske proslave, uz kratak povijesni osvrt na pandemijske/epidemijske valove kolere u 19. i 20. stoljeću, a zatim će se analizirati lažne vijesti koje su prenosile bečke tiskovine Neue Freie Presse i Wiener Allgemeine Zeitung o pojavi različitih infektivnih bolesti u okolici Velehrada, koje su koincidirale s vrlo iscrpnim i objektivnim vijestima tih istih tiskovina o protuepidemijskim mjerama vezanim uz koleru. S obzirom na iznimnu učestalost pandemijskih valova kolere u 19. stoljeću, ukratko će se iznijeti podaci iz specijalnoga monografskog izdanja Svjetske zdravstvene organizacije (SZO) posvećenog istraživanju epidemija/pan-

\footnotetext{
${ }^{64}$ Uspostavljanje trajne protuepidemijske zaštite u cijeloj Habsburškoj Monarhiji, u čijem su se sklopu nalazile i hrvatske zemlje, u svrhu reguliranja i organizacije „kužnoga redarstva” trajalo je od vremena cara Karla III. (1710. - 1740.) i objavljivanja serije zdravstvenih odredbi, propisa i zakona sve do normativa iz doba carice Marije Terezije (1740. - 1780.), kad je čitavo javno zdravstvo Monarhije regulirano Zdravstvenim normativom Gerarda van Swietena iz 1770. Vidi: Frank T. Brechka, Gerard Van Swieten and His World 1700-1772 (Den Haag: Martinus Nijhoff, 1970). O zdravstvenoj zakonodavnoj regulativi u vrijeme prosvijećenoga apsolutizma u Habsburškoj Monarhiji u 18. stoljeću, s caricom Marijom Terezijom kao ključnim čimbenikom u promicanju razvoja javnoga zdravstva, u sklopu kojega se posebice analizira Opći zdravstveni pravilnik iz 1770. kao prvi obuhvatniji akt na tom polju, vidi i: Ivana Horbec, Zdravlje naroda - bogatstvo države. Prosvijećeni apsolutizam i počeci sustava javnoga zdravstva u Hrvatskoj (Zagreb: Hrvatski institut za povijest, 2015).

${ }^{65}$ Jitka Jonová, „Velehradské pouti ve druhé polovině 19. století - náboženská nebo politcká manifestace?", Východočeský sbornik historický 23 (2013): 320.
} 
demija kolere u 19. i 20. stoljeću. ${ }^{66}$ Kolera se kronološki pojavljuje i bilježi u posebice snažnom obliku u četvrtom pandemijskom valu u 19. stoljeću, koji je trajao od 1863. do 1875., što je svakako moglo poslužiti za izazivanje osjećaja opasnosti kod lokalnoga moravskog stanovništva u vezi s ad hoc proglašenom epidemijom u Velehradu i okolici 1885., koja je inače koincidirala s petim pandemijskim valom kolere (1881. - 1896.). U monografiji SZO-a spominje se vrlo ozbiljna epidemija kolere u Habsburškoj Monarhiji 1866., sa znatnom stopom mortaliteta. Ta je epidemija koincidirala s ratom u kojem se ona našla s više država. Naime, tijekom procesa ujedinjenja njemačkih država Austrija se suočila s ambicijama Pruske, koja je također pretendirala na vodeću ulogu u njemačkom ujedinjenju i na kraju je od nje preuzela. Taj se sukob odvijao u širem okviru događanja u kojem Pruska i Austrija u početku djeluju zajedno u suzbijanju danskih pretenzija za Schleswigom i Holsteinom. Nakon rata Pruske i Austrije s Danskom, koji je završio danskim porazom 1864., izbio je 1866. rat Austrije s Pruskom i Kraljevinom Sardinijom (Pijemont) jer je pruski kancelar Otto von Bismarck u zamjenu za austrijsku Lombardiju ponudio savez kralju Kraljevine Sardinije (Pijemont) Vittoriju Emanueleu II., koji se proglasio kraljem Italije 1861., oko koje se 1870. ujedinila Italija. Teško poražena kod Kraljičina Gradca (Königgrätz) u Češkoj 1866., Austrija se morala povući iz Njemačkoga saveza i Kraljevini Sardiniji (Pijemont) ustupiti mletačko područje. Međutim, talijanske ambicije glede Dalmacije sasvim su se izjalovile jer brojčano nadmoćnije brodovlje Kraljevine Sardinije (Pijemont) koje napada Vis radi stvaranja uporišta za talijansko osvajanje Dalmacije doživljava 20. srpnja 1866. težak poraz od habsburškoga brodovlja (s većinskom hrvatskom posadom) pod zapovjedništvom admirala Wilhelma von Tegetthoffa. No poraz kod Kraljičina Gradca prisilio je Habsburšku Monarhiju na potpisivanje mira u Pragu (23. kolovoza 1866.), čime je bio otvoren put ujedinjenju Njemačke pod vodstvom Pruske (1871.). To je također bio uvod u dualistički preustroj Habsburške Monarhije u Austro-Ugarsku Monarhiju 1867., kao nove forme državnoga uređenja, radi njezina preživljavanja, o čemu se ovdje ne može opširnije govoriti, kao ni o oblikovanju istočne politike Austro-Ugarske Monarhije nakon izbacivanja iz Njemačkoga saveza, usmjerene napose na ovladavanje Balkanom do Soluna. Ključni razlog spominjanja austro-pruskoga i austro-talijanskoga rata 1866. jest taj da se epidemija kolere 1866. najsnažnije očitovala upravo na području Češke i Moravske te Italije, što je svakako bilo povezano s masovnim kretanjem vojske zaraćenih strana kroz ta područja zahvaćena ratnim operacijama, odnosno s gotovo redovitom pojavom infektivnih bolesti i epidemija u zonama ratnih operacija i na ratom opustošenim područjima. Ako uzmemo kao predložak podatke iz popisa stanovništva Habsburške Monarhije iz

\footnotetext{
${ }_{66}$ Robert Pollitzer, Satya Swaroop, William Burrows, Cholera, World Health Organisation Monograph Series, No. 43 (Ženeva, Palais des Nations: George Williams Hooper Foundation, University of California, San Francisco, USA /Formerly of the Division of Communicable Disease Services/; World Health Organisation, 1959).
} 
1857. (sljedeći popis je iz 1869.), prema kojem su Češka i Moravska ukupno imale 6572619 stanovnika, ${ }^{67}$ nedvojbeno je da je pomor od kolere u Češkoj i Moravskoj 1866. od 80000 osoba (gotovo identičan broju umrlih od kolere u Španjolskoj od lipnja do kolovoza 1885.) bio znatan (1,2\%). Bile su zahvaćene i druge austrijske zemlje u sklopu Habsburške Monarhije, a u Ugarskoj je koleri podleglo čak 30 000 ljudi. ${ }^{68}$ Uzevši u obzir da su u Češkoj i Moravskoj traumatična sjećanja na koleru iz 1866. još uvijek bila vrlo živa, vijesti o pojavi više infektivnih bolesti u okolici Velehrada sredinom lipnja 1885. nedvojbeno su potaknule strah od zdravstvene prijetnje $\mathrm{u}$ širim slojevima stanovništva i na taj način, poticanjem straha u lokalnim zajednicama, također efektivno pridonijele propasti velikoga slavenskoga katoličkog hodočašća na Velehradsku proslavu 5. srpnja 1885.

S obzirom na to da je kolera u svojem petom pandemijskom valu (1881. - 1896.) koincidirala s proglašenjem epidemije u Velehradu, a u četvrtom pandemijskom valu izazvala teške posljedice i velike ljudske gubitke upravo na području Češke i Moravske, ukratko će se prikazati njezini pandemijski valovi nakon što se početkom 19. stoljeća počela širiti iz Indije, u kojoj je stoljećima bila prisutna kao endemska bolest. Bakterija kolere mikrobiološki je registrirana i analizirana 1883. Ugledni njemački bakteriolog Robert Koch te je godine mikrobiološkim pretragama utvrdio da je bakterija, nazvana Vibrio cholerae, glavni medij prijenosa uzročnika bolesti. U Europi se kolera širila vodenim putovima i novoizgrađenim željezničkim prugama i stizala u rastuće industrijske gradove, gdje su njezinu širenju pogodovali slaba higijena, manjkava ili nepostojeća kanalizacija i opskrba nezdravom vodom. Primjer za to je i činjenica da se u Londonu širila brže u gradskim četvrtima koje su se opskrbljivale vodom iz donjega dijela Temze, gdje su se nalazili i kanalizacijski ispusti, nego u onima koje su vodom opskrbljivane iz gornjega dijela iste rijeke. $S$ obzirom na to, Tatjana Buklijaš ustvrdila je da se kolera može smatrati paradigmatskom bolešću Europe u doba industrijalizacije. ${ }^{69}$ Inače, kolera je bila endemska bolest u Indiji još od pradavnih vremena, a uvjete za njezino širenje u Europu stvorilo je tek širenje britanskoga kolonijalnog imperija u 19. stoljeću. ${ }^{70} \mathrm{U}$ hrvatskoj historiografiji ne postoje monograf-

67 Vidi: Statistische Übersichten über die Bevölkerung und den Viehstand von Österreich nach der Zählung vom 31. October 1857 (Beč: Aus der Kaiserlich-königlichen Hof- und Staatsdruckerei, 1859), 4-5, pristup ostvaren 27. 5. 2021., https://archive.org/details/statistischebers00aust/mode/2up.

68 „No doubt can exist that the war waged by Prussia against Austria [1866., op. a.] and her allies, as well as the hostilities between Austria and Italy, exerted a most unfavourable influence on the cholera situation in central Europe. [...] The situation was also most serious in war-torn Austria-Hungary, resulting in a cholera mortality of about 80000 in Bohemia and Moravia, while other parts of Austria also suffered, and 30000 succumbed to the disease in Hungary. In Italy there was a serious cholera recrudescence in 1866, for which the military operations were largely responsible." Pollitzer, Swaroop, Burrows, Cholera, 33.

${ }^{69}$ Tatjana Buklijaš, „Kolera: 'nova bolest' u doba revolucija”, Hrvatska revija (obnovljeni tečaj) 3 (2003), br. 1: 91.

70 Buklijaš, „Kolera: 'nova bolest' u doba revolucija”, 91. 
ske studije posvećene epidemijama kolere, ali je objavljeno nekoliko relevantnih znanstvenih radova na koje je u okviru svojih istraživanja upozorila Irena Ipšić, koji su, izuzev rada $\mathrm{T}$. Buklijaš, napose usmjereni istraživanju pojava kolere $\mathrm{u}$ hrvatskim zemljama. ${ }^{71}$ Prva pandemija kolere, koja je započela 1817. vojnim pohodom markiza Hastingsa, slijedeći putove britanskih imperijalnih trgovačkih i političkih komunikacija, zahvatila je Kinu, Japan i dijelove istočne Afrike, no nije prešla preko Kavkaza u Europu. ${ }^{72}$ Drugi val, koji je započeo 1829., zahvatio je 1836./1837. cijelu Europu i sjevernu Afriku, a preko Atlantika i istočnu obalu Sjeverne Amerike. ${ }^{73}$ Taj se val preko Galicije u Europi najprije proširio na Austriju te zahvatio Beč u kolovozu 1831. Prije toga u lipnju 1831. Ugarska je već bila gotovo potpuno zahvaćena epidemijom, koja se ondje očitovala u posebice snažnom obliku. Iz gornje Italije kolera se 1836. proširila na kanton Tessin (Ticino) u Švicarskoj i Tirol. Zahvatila je i neka područja Istre, Hrvatske, Dalmacije, Kranjske i Štajerske, šireći se i na sjeverne dijelove Austrije i Ugarsku. ${ }^{74}$ Treći pandemijski val kolere, 1841. - 1859., zahvatio je napose 1852. Indiju, iz koje se proširio na Perziju i Mezopotamiju (dio današnjega Iraka, uključujući i dijelove istočne Sirije te manje dijelove Turske i Irana, op. a.), 1853. zahvaća sjeverne dijelove Europe, a potom i južne, a širi se i na Sjedinjene Američke države i Meksiko. Prijevoz trupa iz južne Francuske zbog Krimskoga rata (1853. - 1856.) prouzročio je pojavu kolere u Grčkoj i Turskoj. ${ }^{75}$ Od svih zemalja tijekom trećega pandemijskog vala najviše je stradala Austrija, u kojoj je tada od posljedica kolere umrlo 270915 ljudi. ${ }^{76}$ Godine 1856. slabi njezino širenje Europom. Osim u Španjolskoj i Portugalu (uključujući Madeiru), kolera nije izazvala veliku smrtnost u Europi 1856. - 1858. Četvrti pandemijski val (1863. - 1875.) zahvatio je gotovo cijeli svijet te se po zemljopisnim razmjerima radilo o najvećoj pandemiji. U tom razdoblju kolera ponovno snažno zahvaća područje Habsburške Monarhije, napose Češku i Mo-

\footnotetext{
${ }_{71}$ Među relevantnim historiografskim radovima posvećenim koleri u hrvatskoj historiografiji I. Ipšić posebice je izdvojila citirani rad T. Buklijaš „Kolera: 'nova bolest' u doba revolucija”, u kojem se analiziraju glavni pravci širenja pandemijskih valova kolere tijekom 19. stoljeća, zatim rad Mihovila Bolonića „Kužne bolesti u prošlosti otoka Krka (s posebnim osvrtom na koleru 1855. godine)”, Krčki zbornik 6 (1975): 79-132, u kojem se analiziraju demografski gubici tijekom epidemije kolere 1855. u pojedinim naseljima na otoku Krku, te radove Slavena Bertoše „Zapisi o koleri u jednoj istarskoj župi god. 1855.", Historijski zbornik 41(1988): 245-251, u kojem se analiziraju razmjeri kolere na području Istre u kolovozu i rujnu 1855., i Vinka Juzbašića „Kolera u Bošnjacima 1913. godine”, Hrašće: časopis za književnost, umjetnost i povijest 28 (2003): 77-81. Vidi: Irena Ipšić, „Demografske i društveno-gospodarske posljedice epidemije kolere: Primjer epidemije u Drenovcima 1873. godine”, Scrinia Slavonica: Godišnjak Podružnice za povijest Slavonije, Srijema i Baranje Hrvatskog instituta za povijest 10 (2010): 528.

72 Buklijaš, „Kolera: 'nova bolest' u doba revolucija”, 91.

73 Pollitzer, Swaroop, Burrows, Cholera, 21.

74 Pollitzer, Swaroop, Burrows, Cholera, 21-26.

75 Pollitzer, Swaroop, Burrows, Cholera, 30.

76 Ipšić, „Demografske i društveno-gospodarske posljedice epidemije kolere”, 529.
} 
ravsku u vrijeme rata Pruske i Kraljevine Sardinije (Pijemont) protiv Habsburške Monarhije 1866., što je već prije spomenuto. Peti pandemijski val kolere (1881. - 1896.) bio je ograničenijega opsega, ali je ponovno zahvatio veći dio Europe, Azije, sjeverne Afrike i Amerike. U kolovozu 1887. osobito se snažno proširio po svim dijelovima Italije. Mnogi slučajevi oboljenja zabilježeni su i u Rimu. Umrlo je više tisuća ljudi. Epidemija je obuzdana tek početkom prosinca 1887. Ustvari se radilo o posljednjoj fazi epidemije koja se u Kraljevini Italiji pojavila još 1884./1885. ${ }^{77}$ Tijekom toga vala kolera je ugrozila i Austro-Ugarsku Monarhiju, a posebna bojazan od njezina širenja zavladala je u hrvatskim zemljama, napose zbog nepostojanja odgovarajućih infektivnih medicinskih institucija. ${ }^{78}$ Tek je šesti val kolere, koji je nastupio potkraj 19. stoljeća i trajao najdulje, od 1899. do 1923., bio naznaka njezina jenjavanja, zadržavši se uglavnom u Aziji. U Europi se pojavljuje tek izolirano, u Ugarskoj 1909./1910. te u nekim drugim zemljama. Godine 1913. javlja se u zemljama koje su graničile s Osmanskim Carstvom, zbog kontakta s njegovim azijskim vojnim postrojbama tijekom balkanskih ratova 1912./1913. U vrijeme Prvoga svjetskog rata (1914. - 1918.) pojavljuje se zaraza u

77 Vidi: Giovanni Battista Morana, Il colera in Italia negli anni 1884-1885. Relazione a S. E. il Cav. Avv. Agostino Depretis presidente del Consiglio dei Ministri e Ministro dell'Interno (Rim: Tip. Elzeviriana, 1885).

78 U vezi s kolerom koja se približila kraljevinama Hrvatskoj i Slavoniji, 1885. u Liečničkom viestni$k u$ objavljen je Memorandum hrvatsko-slavonskoga liečničkoga sbora slav. gradskom poglavarstvu zagrebačkom o potrebi poduzimanja preventivnih mjera. Bečke tiskovine izvijestile su i o angažmanu Hrvatsko-slavonske zemaljske vlade, koja je s tim u vezi uputila cirkularnu naredbu mjesnim organima uprave: „Agram, 27. Jun. Die Landesregierung hat an sämtliche Behörden in Angelegenheit der Cholera eine Circular-Verordnung gerichtet". Wiener Allgemeine Zeitung. Morgenblatt, Nr. 1913, 28. Juni 1885, 7. Hrvatsko-slavonski liječnički zbor poduzeo je i konkretnije mjere glede mogućega širenja kolere na Trojednu Kraljevinu te je sa svoje sjednice održane 30. ožujka 1885. Gradskom poglavarstvu uputio preporuku za neodgodivu izgradnju infektivne bolnice u Zagrebu. Pritom se na urgentnost te izgradnje upozorava posebice s obzirom na pogibeljne i vrlo česte pandemijske valove kolere u bližem okruženju Trojedne Kraljevine: „Suvišno bi bilo spominjati sve strahote, koje sa sobom donaša veća ili pogibeljnija epidemija, kao n. pr. kolera, koja nam lanjske godine nije bila vrlo daleko; strahote, koje bi se preko mjere povećati morale, kad nemamo niti izolovanih zavoda, kamo bi bolestnike smještali, te ih odlučivali od zdravih. Nu ne samo za slučaj kolere, već i onda, da n. pr. nastane samo pošast boginja, naše bi dvie bolnice [ustvari ih je u to vrijeme bilo tri: Zagrebačka opća bolnica, svečano otvorena 23 . kolovoza 1804., kojom su upravljali redovnici Milosrdne braće te joj je službeni naziv bio Javna opća bolnica Milosrdne braće na Jelačićevom trgu, Zavod za umobolne u Stenjevcu (1879.) i Vojna bolnica u Vlaškoj (1861.), op. a.] služile više razširenju pošasti, nego li njezinu zatiranju; one bi bile nešto posve drugčijeg, no što jim je svrha, bile bi leglo pošasti”. Liečnički viestnik: organ Sbora liečnika kraljevina Hrvatske i Slavonije, 7 (1885), br. 2: 24-25. O ozbiljnosti shvaćanja javnozdravstvene opasnosti tijekom petoga pandemijskog vala kolere (1881. - 1896.) u Zagrebu svjedoči činjenica da je na „Zelenom brijegu" 1893. sagrađena bolnica za infektivne bolesti. U početku je nazivana kolera bolnica ili kužna bolnica, zatim Gradska kužna bolnica na "Zelenom brijegu”, a začetak je današnje Klinike za infektivne bolesti „Dr. Fran Mihaljević” na Mirogojskoj cesti. Ta bolnica, odnosno bolnička zgrada u kojoj je utemeljena, do danas je sačuvala prvotni vanjski izgled, a u njezinu sklopu nalazi se Odjel za infektivne bolesti novorođenčadi i dojenčadi Klinike za infektivne bolesti „Dr. Fran Mihaljević”. „Od kužne bolnice na 'Zelenom brijegu' do suvremene klinike”, Klinika za infektivne bolesti „Fran Mihaljević”, pristup ostvaren 3. 6. 2021., https://bfm.hr/wp-content/uploads/2019/10/Od-kuzne-bolnice-1.pdf. 
Austriji (1914. - 1916.), što je bila posljedica transporta ruskih, a zatim i srpskih zarobljenika. U studenom 1914. austrijske trupe koje su došle s područja Volinija-Podolsk (povijesna regija koja je obuhvaćala područje jugoistočne Poljske, jugozapadne Bjelorusije i zapadne Ukrajine) prenose zarazu u prusku Šlesku, ali ona se nije ozbiljnije proširila. ${ }^{79}$ Smrtnost od kolere u Indiji ponovno je premašila pola milijuna 1918. (556 533 umrlih) i 1919. (565 166 umrlih). Godine 1919. proširila se na Javu, Tajland i Kinu, s također vrlo visokom stopom smrtnosti. ${ }^{80}$ Sporadične pojave kolere moguće je pratiti i između dva svjetska rata, napose $\mathrm{u}$ Rusiji, na području Rostova na Donu (1920. - 1925.). Nakon toga kolera nestaje iz Europe, uz sporadičnu zarazu njemačkih vojnika u Ukrajini 1943., dok su se u Aziji i Africi epidemije često pojavljivale, ali znatno manjega intenziteta, između dva svjetska rata, tijekom, pa i nakon njega. Godine 1947./1948. pojavljuje se u Siriji i Egiptu. U Kini i Indiji pojavljuje se 1950. - 1954. ${ }^{81}$ Ovo su tek vrlo šturi podaci iz citirane, inače vrlo opsežne monografske studije SZO-a o koleri (1019 str.), objavljene 1959., s mnoštvom vrijednih podataka, grafikona te slikovnih prikaza o različitim aspektima njezine pojavnosti i širenja te dosega znanstvenih (napose mikrobioloških) istraživanja. Razlog ovakva širega osvrta bio je posvjedočiti iznimnu istraženost problematike i dokumentiranost ne samo svih većih pandemijskih valova kolere (ukupno šest) nego i niza njezinih sporadičnih pojava (koje se ovdje navode tek u najkraćim crtama).

S obzirom na to da je peti pandemijski val kolere koincidirao s lažnim vijestima o pojavi infektivnih bolesti u okolici Velehrada, ovdje će se ukratko prikazati vrlo odgovorne protuepidemijske mjere koje je Austro-Ugarska Monarhija poduzela radi sprječavanja širenja kolere na svoj teritorij, koje su u krajnjoj diskrepanciji sa zloporabom medicine u političke svrhe koju je austrijska vlada istodobno provodila u južnoj Moravskoj. O koleri u Španjolskoj bečki dnevnici Neue Freie Presse i Wiener Allgemeine Zeitung, koji se analiziraju u ovome radu, donose gotovo svakodnevno vrlo iscrpne i objektivne analize novopristiglih vijesti tijekom lipnja, srpnja i kolovoza $1885 .{ }^{82} \mathrm{Uz}$ osvrt na vrlo odgovorne mjere državnih organa za prevenciju širenja kolere na teritorij Austro-Ugarske Monarhije, u njima se istodobno objavljuju vijesti o navodnoj pojavi više infektivnih bolesti u Velehradu i njegovoj okolici, koje mogu poslužiti kao ogledan primjer neobjektivnoga

\footnotetext{
79 Pollitzer, Swaroop, Burrows, Cholera, 43-44.

80 Pollitzer, Swaroop, Burrows, Cholera, 45.

81 Pollitzer, Swaroop, Burrows, Cholera, 67.

82 Vidi: Neue Freie Presse: Morgenblatt, Nr. 7474, 20. Juni 1885, 7; Morgenblatt, Nr. 7475, 21. Juni 1885, 5; Morgenblatt, Nr. 7494., 11. Juli 1885, 7; Morgenblatt, Nr. 7527, 13. August 1885, 6. Česte vijesti o koleri u Španjolskoj u lipnju i srpnju 1885. nalazimo i u Wiener Allgemeine Zeitungu. Ovdje se navode samo pojedini nadnevci: Abendblatt, Nr. 1900, 15. Juni 1885, 1; Morgenblatt, Nr. 1910, 25. Juni 1885, 2, 7; Morgenblatt, Nr. 1918, 4. Juli 1885, 7; Morgenblatt, Nr. 1919, 5. Juli 1885, 12; Morgenblatt, Nr. 1922, 8. Juli 1885,7 . Navođenje svih relevantnih članaka s tim u vezi zahtijevalo bi poseban rad posvećen spomenutoj temi.
} 
i tendencioznoga izvješćivanja, o čemu će biti više riječi kasnije. S obzirom na opasnost od kolere, Neue Freie Presse u lipnju objavljuje članak „Iz Vrhovnoga sanitarnog vijeća”, u kojem izvješćuje čitatelje da se Vijeće na svojoj sjednici 20. lipnja 1885. bavilo pitanjem hoće li se osim mjera koje je Pomorska uprava već odredila za pomorski promet odrediti i uvesti mjere predostrožnosti protiv širenja epidemije primjerene i za kopneni promet. ${ }^{83}$ Kako je kopneni promet između Španjolske i Austro-Ugarske Monarhije bio neznatan, dugotrajan i moguć samo „ako se dotaknu teritoriji država između njih” i s obzirom na to da je zabrana uvoza iz Španjolske, objavljena u ministarskom Pravilniku od 11. rujna 1884., bila i dalje na snazi, te konačno napominjući da su države koje su u početku bile zainteresirane za obranu od kolere koja se širi iz Španjolske, osobito Francuska, nesumnjivo već poduzele mjere protiv širenja epidemije na njihovo područje, $\mathrm{Vr}$ hovno sanitarno vijeće utvrdilo je da uvođenje posebnih mjera za zaustavljanje (sprječavanje) unošenja kolere iz Španjolske kopnom nije potrebno. ${ }^{84}$ Nadalje, Neue Freie Presse 28. lipnja 1885. izvješćuje o obraćanju austrougarske vlade vladama Njemačkoga Carstva, Francuske, Kraljevine Italije i Švicarske konfederacije sa zahtjevom da joj priopće koje su mjere poduzele glede sprječavanja širenja kolere iz Španjolske. Prema pristiglim priopćenjima, Njemačko Carstvo i Italija ograničili su se na uvođenje mjera na moru glede robe podrijetlom iz Španjolske. Švicarska je izjavila da, budući da nema izravnu komunikaciju sa Španjolskom, prepušta susjednim državama, naime Francuskoj i Italiji, da poduzmu potrebne mjere opreza i stoga sama ne namjerava narediti nikakve mjere. Francuska je uvela višednevno promatranje/kontrolu brodova koji dolaze iz Španjolske. Na kopnenoj granici između Španjolske i Francuske nije uvedena karantena, ali je uveden medicinski nadzor graničnoga, napose željezničkoga prometa. ${ }^{85}$

S tim izvješćima uglednih bečkih tiskovina o preventivnim protuepidemijskim mjerama koje su austrougarske vlasti vrlo sustavno provodile radi sprječavanja širenja kolere na svoj teritorij, ne navodeći zbog ograničenih opsegovnih okvira članka brojne druge izvještaje sličnoga sadržaja, završio bih osvrt na taj segment istraživanja, koji svjedoči o nadasve kompetentnom i iscrpnom izvješćivanju tih listova o koleri u naznačenom razdoblju, i prešao na analizu njihovih vijesti o pojavi više infektivnih bolesti u okolici Velehrada uoči središnje proslave 1000. obljetnice smrti sv. Metoda 5. srpnja 1885., koje svjedoče o dijametralno oprečnom pristupu istih tiskovina u priopćavanju informacija s obzirom na to da se $u$

83 „Aus dem Obersten Sanitätsrathe. - Angesichts des Wiederauftretens der Cholera in Spanien beschäftigte den obersten Sanitätsrath in seiner Sitzung von 20. Juni d. J. die Frage, ob außer den bereits von der Seebehörde für den Seeverkehr angeordneten Maßregeln auch für den Landverkehr schon dermalen die Andordnung von Vorsichtsmaßregeln gegen die Einschleppung der Seuche angezeigt erscheine." Neue Freie Presse. Abendblatt, Nr. 7477, 23. Juni 1885, 1.

${ }^{84}$ Neue Freie Presse. Abendblatt, Nr. 7477, 23. Juni 1885, 1.

${ }_{85}$ Neue Freie Presse. Morgenblatt, Nr. 7482, 28. Juni 1885, 5. Identičnu vijest prenio je istoga dana Wiener Allgemeine Zeitung. Morgenblatt, Nr. 1913, 28. Juni 1885, 5. 
potonjem slučaju u osnovi radilo o lažnim vijestima. To što se prve vijesti o pojavi epidemije u Velehradu i okolici javljaju sredinom lipnja 1885. nipošto nije slučajno jer je preuranjeno obznanjivanje lažnih vijesti moglo dovesti do razotkrivanja obmane prije same proslave, a samim tim ugroziti donesenu epidemiološku mjeru zabrane kretanja, kojom je hodočašće katolika i grkokatolika iz drugih dijelova Austro-Ugarske Monarhije i pravoslavaca i unijata iz Ruskoga Carstva učinkovito onemogućeno. Također zbog ograničenih opsegovnih okvira član$\mathrm{ka}$, upozorit ću samo na pojedine relevantnije priloge u dva spomenuta bečka lista objavljivane od sredine lipnja 1885. čija je svrha bilo stvaranje pretpostavki za opstruiranje središnje Velehradske proslave 5. srpnja od austrougarskih vlasti proglašenjem lažne epidemije, koji čine očitom zloporabu medicine u političke svrhe. Upozorit ću i na osporavajuće, a ponekad i implicitno prijeteće reakcije spomenutih listova na dopise drugih tiskovina iz Austro-Ugarske Monarhije, koje su izražavale sumnju u osnovanost vijesti o epidemiji u okolici Velehrada.

Neue Freie Presse 16. lipnja prenosi vijest iz Brna o tome da je 15. lipnja 1885. državni namjesnički savjetnik dr. Emanuel Kuhn otišao u izvide u Velehrad budući da je u velehradskom okrugu izbilo nekoliko zaraznih bolesti koje bi s obzirom na masovna hodočašća mogle lako poprimiti prijeteći karakter. ${ }^{86}$ Dana 20. lipnja 1885. Neue Freie Presse prenosi vijesti iz Brna ustvrdivši da su, prema službenim istraživanjima, uznemirujuće glasine o širenju infekcija u Velehradu i oko njega znatno pretjerane. Nadalje navodi da su zarazne bolesti koje su se javile u pojedinim zajednicama (mjestima u okolici Velehrada) dijelom u gašenju, a dijelom su se javile tek sporadično i prolaze s najblažim simptomima. Za političke vlasti tvrdi se da su poduzele sve sanitarne mjere, uz pomoć i intervenciju državnih sanitarnih službenika, kojima je difterija, čijim su prijenosnicima označeni hodočasnici, u zaraženim zajednicama suzbijena. Naglašava se da su okružni liječnici proveli epidemiološke mjere uz najstrože poštovanje protokola povjerene im medicinske službe. Iz vijesti o pretjeranosti vijesti o pojavi infektivnih bolesti, njihovu sporadičnom pojavljivanju, najblažim oblicima njihove pojavnosti i njihovu postupnom gašenju jasno je da je na temelju spomenutoga izvještaja vrlo teško steći dojam o pojavi bilo kakve epidemije. No nadasve je znakovito da se kao prijenosnici difterije navode hodočasnici, s očitim ciljem označavanja hodočasnika kao glavnih prijenosnika infektivnih bolesti radi uvođenja mjere zabrane kretanja, da bi se onemogućilo masovno hodočašće na središnju Velehradsku proslavu 5. srpnja 1885., u čemu su austrougarske vlasti na kraju i uspjele. ${ }^{87}$

86 „Brünn [Brno, op. a.], 15. Juni 1885. Der Landes-Sanitäts-Referent, Stattheltereirath Dr. Emanuel
Kuhn, hat sich heute zur Inspection nach Velehrad begaben, da in diesem Bezirke mehrere Infec-
tions-Krankheiten ausgebrochen find, die bei Gelegenheit der Massen-Processionen leicht einen bed-
rochlichen Charakter annehmen könnten.” Neue Freie Presse. Morgenblatt, Nr. 7470, 16. Juni 1885, 8 .
${ }^{87}$ „Brünn, 20. Juni 1885. Die beunruhigenden Gerüchte über die Verbreiturng von Infections-Krank-
heitenin und um Vellehrad, sind, den Amtlichen erhebungen zufolge, bedeutend übertreiben. Zu
einzelnen Gemeinden vorgekommene Infections-Krankheiten sind theils in erlöschen, theils sind 
U svojem izvješću od 23. lipnja Neue Freie Presse javlja da je Die Brünner Morgenpost, dodatak službenim brnskim novinama, potvrdio prisutnost infektivnih bolesti oko Velehrada, u okrugu Ungarisch-Hradisch (Uherské Hradiště), da je općinu Borschitz (Boršice) zahvatila epidemija vodenih kozica i tifusa, a da su se pojedinačni slučajevi prve bolesti dogodili i u Tupesu i Strzibrnitzu (Stř́brnice), šarlaha u Podolima, ospica u Groß Blattnitzu (Blatnice), a sporadični slučajevi šarlaha i vodenih kozica u samom Velehradu. ${ }^{88}$ Iz nastavka članka sasvim je jasno da je svrha tih vijesti o pojavi infektivnih bolesti, premda se kaže da su u "nestajanju”, „sporadične”, a glede simptoma „u najblažoj formi”, bila onemogućiti veliko hodočašće na središnju Velehradsku proslavu 5. srpnja 1885., kao i ograničiti naknadna hodočašća, koja su planirana i u kolovozu i rujnu, odnosno izolirati i svesti proslave na stanovništvo južne Moravske i Češke, pri čemu se $\mathrm{u}$ takvu reduciranom lokalnom kontekstu nastojalo pridonijeti njihovu što svečanijem obilježavanju, ali bez isticanja njihova slavenskoga obilježja i uloge u planovima Svete Stolice o sjedinjenju crkava, što je napose postignuto zabranom putovanja u Velehrad biskupima Posiloviću i Hraniloviću, koji su trebali slaviti starocrkvenoslavensku misu na središnjoj proslavi 5. srpnja, i odvraćanja biskupa Strossmayera od predvođenja hrvatskoga, odnosno hrvatsko-slovenskoga hodočašća. Neue Freie Presse u spomenutom izvješću od 23. srpnja piše da više nema razloga za uzbunu zbog straha od širenja infekcija uzrokovanih brojnijim hodočašćima u Velehrad ove godine zbog tisućljetne proslave Ćirila i Metoda jer su u svim zaraženim zajednicama (mjestima oko Velehrada i u samom Velehradu) noćenja hodočasnika obustavljena i uvedene najstrože epidemiološke mjere, uz intervenciju okružnih liječnika, imenovanih za sve zajednice. Strogo postupanje medicinske policije i informirana suradnja stanovništva, da bi i ubuduće izostale opasnosti od epidemije, trebali bi s pouzdanjem, nastavlja Neue Freie Presse, uspjeti spriječiti da slučajevi infekcije koji se tu i tamo povremeno pojave ometu obilježavanje velike obljetnice. Ističe se kao bitno da se proslava jubileja (središnja proslava 5. srpnja) nikako „ne priguši” iako oko Velehrada vladaju (herrschen) infektivne bolesti šarlah, vodene kozice i tifus. Dakle, nakon što se netom ustvrdilo da su nakon zabrane noćenja hodočasnika u zaraženim mjestima i najstrože primjene epidemioloških mjera, uz intervenciju okružnih liječnika, otklonjeni razlozi za uzbunu, u istom članku odjednom se za infektivne bolesti kaže da i dalje vladaju oko Velehrada. ${ }^{89}$

dieselben nur sporadisch aufgetreten und nehmen den mildesten Verlauf. Es wurden alle Sanitäts-Maßregeln von der politischen Bezirksbehörde und neuerlich unter Intervention der Landes-Sanitäts-Referenten getroffen, ferner wurde in den infizierten Gemeinden das Rächtigen [Rachenbräune, difterija, op. a.] von Wallfahrern eingestellt und die Districktärtzte unter Leitung des Bezirksarztes mit den strengsten Handhabung des Sanitäts-dienstes betraut." Neue Freie Presse. Morgenblatt, Nr. 7475, 21. Juni 1885, 7.

88 Neue Freie Presse. Abendblatt, Nr. 7477, 21. Juni 1885, 2.

89 Neue Freie Presse. Abendblatt, Nr. 7477, 23. Juni 1885, 2. 
Prve vijesti o spomenutim sumnjama pojedinih tiskovina u Austro-Ugarskoj Monarhiji u objektivnost informacija o pojavi infektivnih bolesti u Velehradu i okolnim mjestima Neue Freie Presse objavljuje 2. srpnja 1885., prenoseći da je od dopisnika iz Lemberga (njemački naziv za Lavov, op. a.) primljena vijest sljedećega sadržaja: „Klerikalni poljski krugovi dosad su odlučno čvrsto tvrdili da su izvještaji u bečkim novinama o nepovoljnom zdravstvenom stanju u Velehradu tendenciozno izmišljeni." ${ }^{\prime 90}$ Nadalje se podrobnije informira čitatelje da su nezadovoljstvo i sumnju u osnovanost vijesti o pojavi infektivnih bolesti u okolici Velehrada u Ezasu (dnevniku Krakauer Ezas) iznijeli članovi krakovskoga Odbora za organizaciju Velehradske jubilarne proslave 5. srpnja $1885 .{ }^{91}$ Iz daljnjega teksta proizlazi da je Krakauer Ezas te informacije dobio iz samoga Velehrada jer se iznosi stajalište s tim u vezi tamošnjega okružnog namjesnika, koji je izjavio da zasigurno ne bi trebalo očekivati da će okružne vlasti zanemariti službena izvješća o pojavi zaraznih bolesti u Velehradu, odnosno da će tvrdnje liječnika i gradonačelnika Velehrada koje tome proturječe koristiti kao smjernicu za svoje postupke. Okružni namjesnik nadalje je naglasio da namjerava dosljedno slijediti naputke austrijske vlade, potaknut na to „odgovornošću koja pada na vladu s obzirom na očitu opasnost”, te zabraniti hodočašće u srpnju. ${ }^{92}$ Iz ovoga je očito da su vlasti u Beču odlučile potpuno ignorirati očitovanja velehradskoga gradonačelnika i mjesnih liječnika koja su osporavala pojavu epidemije u Velehradu i okolici, premda su potonji, u neposrednom kontaktu s lokalnom zajednicom, pouzdano znali da je epidemija izmišljena, odnosno da ni u kojem slučaju ne postoje medicinske pretpostavke za njezino proglašenje. To svakako ozbiljno osporava objektivnost analiziranoga članka u Neue Freie Presseu, koji svoje tvrdnje o epidemiološkoj prijetnji na kraju potkrepljuje izvješćima dopisnika iz tiskovine koja je također bila pod očitom kontrolom austrijske vlade, Brünner Zeitunga. U vrlo opširnom dopisu Brünner Zeitunga, uvrštenom u Neue Freie Presse, iznosi se tvrdnja da je za osnovano upućivanje na opasnost bilo mjerodavno pojavljivanje zaraznih bolesti na području oko Velehrada, koje još nisu potpuno nestale premda su se uglavnom pojavile u blažoj formi ili su u nestajanju (navode se pojedinačni slučajevi infektivnih bolesti po pojedinim mjestima), uz tvrdnju da dotični izvještaji nipošto nisu bili pretjerani, što dokazuje sljedeće medicinsko izvješće, koje su službene novine u Brnu objavile tek jučer i iz kojega se pokazalo da su u Velehradu i okolici zapravo vladale vodene kozice, trbušni tifus, šarlah i ospice

90 „Die klerikalen Polenkreise behaupteten bisher entschieden die Mittheilungen der Wiener Blätter über den ungünstigen Gesundheitzustand in Velehrad seien tendenziös erfunden." Neue Freie Presse. Morgenblatt, Nr. 7485, 2. Juli 1885, 5.

${ }_{91}$ Neue Freie Presse. Morgenblatt, Nr. 7485, 2. Juli 1885, 5.

92 „Man dürfte doch nicht den Behörden zumuten, daß dieselben die amtlichen Rapporte über das Auftreten der Infections-Krankheiten in Velehrad ignorieren und sich dafür die gegentheiligen Behauptungen der Arztes und Bürgermeister von Velehrad zur Richtschnur für ihr Vorgehen." Neue Freie Presse. Morgenblatt, Nr. 7485, 2. Juli 1885, 5. 
i da te infektivne bolesti još nisu potpuno iskorijenjene..$^{93}$ Pritom se, naravno, u Neue Freie Presseu nigdje ne upućuje na izvor kojim bi se potvrdila vjerodostojnost navodnoga medicinskog izvješća koje je prenio Brünner Zeitung, niti se prenosi samo medicinsko izvješće, niti se navodi koja ga je medicinska institucija navodno objavila.

S obzirom na to da se novinski članci sličnoga sadržaja pojavljuju u nizu sljedećih brojeva Neue Freie Pressea i Wiener Allgemeine Zeitunga, a kreću se oko iste manipulativne interpretativne okosnice kojoj je cilj bio stvoriti dojam o vjerodostojnosti vijesti o pojavi više infektivnih bolesti u Velehradu i okolici, ovdje bih prekinuo s njihovom analizom i uputio na znanstveni članak Jitke Jonove iz kojega je očito da su moravske medicinske institucije na kraju, osnovano je pretpostaviti i zbog izloženosti pritisku austrijske vlade da potvrde lažne tvrdnje o pojavi više infektivnih bolesti u južnoj Moravskoj, osporile sve medicinske osnove za proglašenje epidemije u Velehradu i okolici. To je krucijalno za utvrđivanje lažnosti vijesti bečkih tiskovina (Neue Freie Presse i Wiener Allgemeine Zeitung) o pojavi epidemije u Velehradu i okolici koje se javljaju od sredine lipnja 1885. jer je, kako je već prije spomenuto, najviše tijelo za procjenu opasnosti od infektivnih bolesti u Moravskoj odbilo sudjelovati u političkoj zloporabi medicine od strane austrijske vlade pokazavši neovisnost $\mathrm{i}$ autonomiju u odnosu na nju unatoč pritiscima s njezine strane kojima je bez daljnjega bilo izloženo, kao i pritiscima policijsko-sanitetske kampanje na terenu koja se kontinuirano provodila, o kojoj su spomenute tiskovine redovito izvješćivale. Naime, 3. srpnja 1885., neposredno uoči središnje Velehradske proslave 5. srpnja, u jeku medijske kampanje spomenutih bečkih tiskovina kojom se nastojalo opravdati uvođenje zabrane kretanja prema Moravskoj, svojim priopćenjem oglasilo se Moravsko zdravstveno vijeće, demantirajući svaku osnovu za zabranu hodočašća u Velehrad iz zdravstveno-epidemioloških razloga. Tvrdnje koje je $s$ tim u vezi iznijela Jitka Jonová, profesorica na Ćirilometodskom teološkom fakultetu Sveučilišta Palacký u Olomoucu, u cijelosti potkrepljuju ključne teze i zaključke iznesene u ovom radu. Jonová je u osvrtu na cijelu situaciju vezanu za proglašenje epidemije ustvrdila da je ministar vanjskih poslova Austro-Ugarske Monarhije Gustav Kálnoky upozorio na potrebu zabrane putovanja u Velehrad ne samo Rusima nego i Slavenima iz Ugarske, a možda i Hrvatima, predvođenim biskupom Strossmayerom, jer Velehradska proslava promiče ideju panslavizma, koji djeluje destruktivno na dualistički sustav Monarhije: „Razlog je bio jasan, susret slavenskih srodnika (obitelji) mogao je dovesti do konsolidacije njihove uzajamnosti, a to je moglo ići na štetu austrougarskoga dualizma, koji legitimira utjecaj Nijemaca u Austriji i Mađara u Ugarskoj." ${ }^{4}$ Jonová je nadalje upozorila na činjeni-

\footnotetext{
${ }_{93}$ Neue Freie Presse. Morgenblatt, Nr. 7485, 2. Juli 1885, 5.

94 Jonová, „Velehradské pouti ve druhé polovině 19. století - náboženská nebo politcká manifestace?", 318-319.
} 
cu da je starocrkvenoslavenska liturgija, prema stajalištu austrougarskih vlasti, promicala interese panslavizma te je u tom kontekstu posebice istaknula biskupa Posilovića i ulogu koja mu je bila namijenjena u središnjoj Velehradskoj proslavi 5. srpnja 1885. Zatim je na osnovi temeljite analize inače vrlo kompleksne problematike ustvrdila da se radilo o lažno proglašenoj epidemiji i zloporabi medicine u političke svrhe, pri čemu su posebnu ulogu u širenju lažnih vijesti o epidemiji u Velehradu i okolici odigrale novine, kao najvažniji onovremeni medij, posebice u radu više puta spomenute dvije bečke tiskovine (usto navodi Fremden-Blatt i još nekoliko bečkih tiskovina). Upozorila je na to da je sve to potaknulo i veliku pozornost bečkoga nuncija Vannutellija na sam događaj: „Problem navodne velehradske epidemije, koja je hodočasnicima zapriječila put, te novinski članci koji pokazuju da se radilo o politički motiviranome neprijateljstvu vlade, nisu zaobišli pozornost nuncija. Taj događaj utjecao je na sudjelovanje hodočasnika [osujetivši ga, op. a.], ali je prije svega bio sramotan za Beč. Informacije o zaraznim bolestima u okolici Velehrada pojavljuju se u novinama od sredine lipnja 1885. Da su se počele pojavljivati neposredno prije glavne proslave, bile bi previše bliješteće [uočljive, op. a.]. [...] boginje kod djece oko Velehrada i slične bolesti, a u novinama je bilo vijesti i o tifusu i skorbutu. Iz toga su razloga neka hodočašća postupno zabranjivana." ${ }^{95}$ Jonová zatim upozorava na višekratno spomenuto sasvim nedvosmisleno očitovanje Moravskoga zdravstvenog vijeća glede vijesti o epidemiji: „Izvanredni sastanak Moravskoga zdravstvenog vijeća, održan 3. srpnja, izdao je priopćenje da nema potrebe zabraniti hodočašća u Velehrad iz zdravstveno-epidemioloških razloga." ${ }^{96}$ Iz nastavka izlaganja J. Jonove vidljivo je da je, kao i Luboslav Hromják, preuzela netočne podatke o Strossmayerovu sudjelovanju u Velehradskoj proslavi: „Strana hodočašća (Strossmayer) najčešće su stizala u kolovozu. ${ }^{\text {"97 }}$ Glede samoga karaktera velehradskih proslava, istaknula je da su snažno djelovale na poticanje nacionalnoga osjećaja u Češkoj i Moravskoj unatoč tome što je kod Čeha primarnu ulogu u tom smislu imao sv. Vaclav, dok su na sv. Ćirila i Metoda gledali kao na zaštitnike Slavena općenito, sve do 1863., kad je papa Pio IX. dopustio proslavu njihova blagdana 5. srpnja vjernicima u Češkoj, Moravskoj i Hrvatskoj, a papa Lav XIII., proglasivši ih enciklikom Grande munus (30. rujna 1880.) svecima opće Crkve, uvrstio ih u opći Rimski kalendar. ${ }^{98}$ Citirani članak J. Jonove može se bez daljnjega ocijeniti kao iznimno važan znanstveni doprinos istraživanju vrlo kompleksne problematike u vezi $\mathrm{s}$

\footnotetext{
95 Jonová, „Velehradské pouti ve druhé polovině 19. století - náboženská nebo politcká manifestace?", 320 .

96 Jonová, „Velehradské pouti ve druhé polovině 19. století - náboženská nebo politcká manifestace?", 320 .

97 Jonová, „Velehradské pouti ve druhé polovině 19. století - náboženská nebo politcká manifestace?", 320 .

98 Jonová, „Velehradské pouti ve druhé polovině 19. století - náboženská nebo politcká manifestace?", 320 .
} 
Velehradskom proslavom 1885., a glede ovoga rada napose je važan jer podatkom o očitovanju Moravskoga zdravstvenog vijeća od 3. srpnja 1885., da ne postoji potreba za zabranom hodočašća u Velehrad iz zdravstveno-epidemioloških razloga, neprijeporno potkrepljuje u njemu iznesene argumente o zloporabi medicine $\mathrm{u}$ političke svrhe proglašenjem lažne epidemije u Moravskoj 1885.

\section{Zaključak}

U historiografskom osvrtu na, u znanstveno-istraživačkom smislu, uglavnom nepoznate aspekte jednoga važnoga povijesnog događaja - proslave tisućite obljetnice smrti sv. Metoda u Velehradu 5. srpnja 1885. - u radu se na temelju analize dostupnoga relevantnoga arhivskoga gradiva i literature utvrđuje da ne postoje nikakvi vjerodostojni podaci o tome da se epidemija u okolici Velehrada, čijim su proglašenjem vlasti Austro-Ugarske Monarhije u dogovoru s Ruskim Carstvom onemogućile slavenskim hodočasnicima pristup proslavi, zaista dogodila. Velehradsku proslavu, kojom se slavljenjem liturgije na starocrkvenoslavenskom jeziku težilo afirmirati ideju crkvenoga sjedinjenja kršćanskoga Istoka i Zapada, obje su države smatrale političkom prijetnjom. Austro-Ugarska Monarhija držala je da starocrkvenoslavenska liturgija afirmira panslavističke tendencije te da se njome otvara put penetraciji Ruskoga Carstva na slavenska područja Monarhije, a Rusko Carstvo bilo je izrazito protiv njezine afirmacije kod katoličkih Slavena, držeći da ona potiče katolički prozelitizam i „unijaćenje” te afirmaciju u Ruskom Carstvu potlačenih grkokatolika. Također ju je smatralo opasnom za svoje vanjskopolitičke interese zbog težnje Svete Stolice za pridobivanjem pravoslavnih balkanskih država na crkvenu uniju, što bi znatno omelo planove Ruskoga Carstva da preko njih ostvari dominaciju na Balkanu i stvori osnovu za prodor na topla mora. Kako o spomenutoj epidemiji nema nikakvih podataka u suvremenim medicinskim publikacijama, koje su u to vrijeme, s obzirom na vrlo dinamičan razvoj mikrobiologije, već vrlo pedantno bilježile pojavnost svih tada prisutnih otkrivenih infektivnih bolesti na globalnoj razini, iznosi se zaključak da se ta epidemija u Moravskoj 1885. uopće nije dogodila te upozorava na taj događaj kao na jedno od najranijih povijesnih svjedočanstava o zloporabi medicine $u$ političke svrhe. Taj se zaključak nepobitno posvjedočuje podatkom koji u svojem radu donosi povjesničarka Jitka Jonová, o očitovanju Moravskoga zdravstvenog vijeća od 3. srpnja 1885. kojim se ustvrdilo da ne postoji potreba za zabranom hodočašća u Velehrad iz zdravstveno-epidemioloških razloga. Zabrana kretanja koja je uvedena uoči Velehradske proslave 1885. uzima se kao osnova za zauzimanje kritičkoga stava prema svim kasnijim zloporabama epidemija u političke svrhe, a i kao predložak za propitivanje teških zloporaba medicine u 20. stoljeću, od kojih su pojedine imale za svrhu ograničenje temeljnih ljudskih prava i sloboda, a neke su bile i zločin protiv čovječnosti (napose eksperimenti na ljudima tijekom Drugoga svjetskog rata, ali i nakon njega, sve do recentnoga 
razdoblja). ${ }^{99} \mathrm{U}$ naznačenom kontekstu ovaj rad pledira i na utvrđivanje načelne legitimnosti propitivanja svih eventualnih zloporaba medicine tijekom aktualne pandemije Covida-19 kako jedini okvir za njihovo kritičko propitivanje ne bi bile različite „teorije zavjere”, posebice s obzirom na odluke i mjere kojima se ukidaju ili ozbiljno ograničavaju zakonom i ustavom zajamčena prava građana, jer je povijesno nedvojbeno dokazano da je vrlo tanka nit koja dijeli opravdane javnozdravstvene mjere i odluke i domenu političke arbitrarnosti i ugrožavanja temeljnih ljudskih prava i sloboda. $S$ tim u vezi napose je važno upozoriti na to da postoji i asocijativna poveznica između epidemioloških mjera iz 1885. i onih uvedenih tijekom pandemije Covida-19 jer je u oba slučaja ograničenje kretanja, premda različitoga opsega, glavna restriktivna mjera. Pritom se u radu ne namjeravaju ni na koji način sugerirati druge asocijativne poveznice među dvama slučajevima, a posebno se ne kani dovoditi u pitanje načelna opravdanost mjera koje se provode u cilju suzbijanja aktualne pandemije. Međutim, na primjeru presedana iz 1885., slučaja očite zloporabe medicine u političke svrhe, upozorava se na nužnost utvrđivanja načelne dopustivosti propitivanja svih restriktivnih odluka i mjera javnozdravstvenih autoriteta u svim slučajevima epidemioloških prijetnji $s$ jedne strane te potrebe transparentnoga predočavanja razloga i konsenzualnoga određivanja kriterija prema kojima se proglašavaju i provode pojedine epidemiološke mjere od strane znanstvenih autoriteta iz područja mikrobiologije, virologije i molekularne biologije, napose s obzirom na kriterij razmjernosti tih mjera. Sve to ističe se kao nužno da se ne bi dovelo u pitanje povjerenje građana u odluke i mjere državnih i drugih institucija koje upravljaju kriznim situacijama, posebice u vrijeme globalne pandemije s kakvom se svijet upravo suočava.

\footnotetext{
99 Vidi o tome opširnije: Roksandić Vidlička, Galiot, „Eksperimenti nad ljudima kao zločin protiv čovječnosti: od nürnberškog medicinskog suđenja do predmeta Pfizer”, 186-253.
} 


\section{Neobjavljeni izvori}

Hrvatska - Arhiv Hrvatske akademije znanosti i umjetnosti - fond Ostavština Josipa Jurja Strossmayera, XI-A, Korespondencija, Pisma Strossmayeru (48), Kosta Vojnović (HR-AHAZU, F/OJJS, XI-A-48, Voj. Ko., br. 1-448).

Hrvatska - Arhiv Hrvatske akademije znanosti i umjetnosti - fond Ostavština Josipa Jurja Strossmayera, XI-A, Korespondencija, Pisma Strossmayeru (49), Lujo Vojnović (HR-AHAZU, F/OJJS, XI-A-49, Voj. Lu., br. 1-9).

Hrvatska - Hrvatski državni arhiv, Zagreb - fond 781 - Obitelj Vojnović, Spisi za historijat obitelji.

Hrvatska - Nacionalna i sveučilišna knjižnica u Zagrebu - Zbirka rukopisa i starih knjiga, fond R 5622 b, Vojnović Kosta, Korespondencija (HR-NSK, ZRiSK, VKK, R 5622 b).

\section{Objavljeni izvori i literatura}

Arendt, Hannah. Eichmann u Jeruzalemu: izvještaj o banalnosti zla. Zagreb: Naklada Jesenski i Turk, 2020.

Artuković, Mato. „Ante Starčević i Židovi (prema pisanju lista Sloboda)”. Časopis za suvremenu povijest 42 (2010), br. 2: 483-511.

„Austro-Ugarska”. Hrvatska enciklopedija, mrežno izdanje. Leksikografski zavod „Miroslav Krleža”. Pristup ostvaren 27. 4. 2021. https://enciklopedija.hr/natuknica.aspx?ID=4697.

Balabanić, Josip; Kolanović, Josip, prir. Korespondencija Josip Juraj Strossmayer - Serafin Vannutelli, 1881-1887. Zagreb: Hrvatski državni arhiv; Kršćanska sadašnjost; Dom i svijet, 1999.

Barac, Fran. „Nadbiskup Dr. Juraj Posilovič”. Katolički list 65 (1914), br. 18: 213-218.

Beham, Markus Peter; Rohdewald, Stefan. „Kyrill und Method”. U: Religiöse Erinnerungsorte in Ostmitteleuropa. Konstitution und Konkurrenz im nationenund epochenübergreifender Zugriff, uredili Joachim Bahlcke, Stefan Rohdewald i Thomas Wünsch, 473-493. Berlin: Akademie Verlag, 2013.

Brechka, Frank T. Gerard Van Swieten and His World 1700-1772. Den Haag: Martinus Nijhoff, 1970.

Buklijaš, Tatjana. „Kolera: 'nova bolest' u doba revolucija”. Hrvatska revija (obnovljeni tečaj) 3 (2003), br. 1: 90-93.

„Ćiril i Metod, sv." Hrvatska enciklopedija, mrežno izdanje. Leksikografski zavod „Miroslav Krleža”. Pristup ostvaren 6. 4. 2021. https://www.enciklopedija.hr/natuknica.aspx?ID=13585. 
Dvije korizmene okružnice dvaju hrvatskih biskupa - J. J. Štrosmajera i J. Posilovića. Zagreb: F. Fišer i dr., 1885.

Gretić, Goran. „Hannah Arendt i Kant: Pokušaj zasnivanja jedne 'kritike političke rasudne snage'”. Politička misao 40 (2003), br. 4: 101-125.

Grijak, Zoran. Politička djelatnost vrhbosanskog nadbiskupa Josipa Stadlera. Zagreb; Sarajevo: Hrvatski institut za povijest; Dom i svijet; Vrhbosanska nadbiskupija, 2001.

Grijak, Zoran. „Barski nadbiskup Šimun Milinović (1886. - 1910.) i svetojeronimska afera". U: Hrvatsko-crnogorski dodiri / crnogorsko-hrvatski dodiri: identitet povijesne i kulturne baštine Crnogorskog primorja, uredila Lovorka Čoralić, 489-520. Zagreb: Hrvatski institut za povijest; Matica hrvatska, 2009.

Grijak, Zoran. „Korespondencija Šimun Milinović - Josip Juraj Strossmayer kao povijesni izvor". Zbornik Odsjeka za povijesne znanosti Zavoda za povijesne $i$ društvene znanosti Hrvatske akademije znanosti i umjetnosti 36 (2018): 215-255.

Grijak, Zoran. „O nacionalno-političkim aspektima zahtjeva za afirmacijom glagoljaške liturgije u hrvatskim zemljama od sredine 19. do početka 20. stoljeća”. Croatica Christiana periodica 43 (2019), br. 83: 81-119.

Grijak, Zoran; Ćosić, Stjepan. Figure politike: Lujo Vojnović i Robert William Seton-Watson. Zagreb: Hrvatski državni arhiv, 2012.

Horbec, Ivana. Zdravlje naroda - bogatstvo države. Prosvijećeni apsolutizam i počeci sustava javnoga zdravstva u Hrvatskoj. Zagreb: Hrvatski institut za povijest, 2015.

Hromják, Luboslav. „Josip Juraj Strossmayer und der katholische Slawismus aus slowakischer Perspektive". U: Josip Juraj Strossmayer 1815-2015: Wien, 21. Mai 2015. - Roma, 9 dicembre 2015, uredili Darija Damjanović, Grgo Grbešić i Tomislav Mrkonjić, 155-184. Đakovo: Katolički bogoslovni fakultet u Đakovu Sveučilišta Josipa Jurja Strossmayera u Osijeku, 2017.

Hrvatski leksikon, svezak 2, glavni urednik Antun Vujić. Zagreb: Leksikografski zavod „Miroslav Krleža”, 1997.

Ipšić, Irena. „Demografske i društveno-gospodarske posljedice epidemije kolere: Primjer epidemije u Drenovcima 1873. godine”. Scrinia Slavonica: Godišnjak Podružnice za povijest Slavonije, Srijema i Baranje Hrvatskog instituta za povijest 10 (2010): 527-545.

Jakšić, Grgur. Iz novije srpske istorije. Abdikacija kralja Milana i druge rasprave. Beograd: Prosveta, 1953.

Jakulj, Ivan. „Međunarodni ugovori Svete Stolice i Crne Gore: Povijesno-pravni vid". Crkva u svijetu 48 (2013), br. 2: 236-261. 
Jonová, Jitka. „Velehradské pouti ve druhé polovině 19. století - náboženská nebo politcká manifestace?" Východočeský sbornik historický 23 (2013): 307-324.

Jurišić, Blaž, prir. Ante Starčević. Izabrani spisi. Zagreb: Izdanje Hrvatskog izdavalačkog bibliografskog zavoda, 1943.

Lauc, Zvonimir. „Načelo vladavine prava u teoriji i praksi”. Pravni vjesnik: časopis za pravne i društvene znanosti Pravnog fakulteta Sveučilišta Josipa Jurja Strossmayera u Osijeku 32 (2016), br. 3-4: 45-67.

Liečnički viestnik: organ Sbora liečnika kraljevina Hrvatske i Slavonije (Zagreb), 1885.

Lukić, Milica. „Ćirilometodske okružnice biskupa J. J. Strossmayera u Glasniku Biskupija Bosanske i Sriemske od 1873. do 1900. godine”. U: Muka kao nepresušno nadahnuće kulture - Vukovar kao paradigma muke. Zbornik radova 4. međunarodnoga znanstvenog simpozija, uredio Jozo Čikeš, 146-161. Zagreb: Udruga Pasionska baština, 2004.

Lukić, Milica. „Strossmayerov projekt obnove ćirilometodske baštine”. Anali Zavoda za znanstveni i umjetnički rad u Osijeku 27 (2011): 67-96.

Markus, Tomislav. „Korespondencija Josipa J. Strossmayera i Koste Vojnovića kao povijesni izvor". Časopis za suvremenu povijest 36 (2004), br. 2: 581-595.

Markus, Tomislav. „Korespondencija Strossmayer-Vojnović: Izabrani dokumenti”. Zbornik Odsjeka za povijesne znanosti Zavoda za povijesne i društvene znanosti Hrvatske akademije znanosti i umjetnosti 25 (2007): 331-383.

Matković, Stjepan. „Ambivalentnost pravaškog odnosa prema Rusiji i Rusima”. Međunarodna znanstvena konferencija HRVATSKA - RUSIJA / ХОРВATИЯ РОССИЯ. Povijesne veze i iskušenja uzajamnosti, Zagreb, 24. svibnja 2018. Kratki sažetak referata.

Medlicott, William Norton. „Diplomatic Relations after the Congress of Berlin”. Slavonic and East European Review 8 (1929), br. 22: 66-79.

Medlicott, William Norton. The Congress of Berlin and After: A Diplomatic History of the Near Eastern Settlement, 1878-1880. London: Methuen and Company, 1938.

Milaš, Nikodim. Slavenski apostoli Kiril i Metodije i istina pravoslavlja: Povodom rimskog pokreta u 1880-81 god. protivu pravoslavne crkve. Zadar: Pečatnja Iv. Vodicke, 1881.

Morana, Giovanni Battista. Il colera in Italia negli anni 1884-1885. Relazione a S. E. il Cav. Avv. Agostino Depretis presidente del Consiglio dei Ministri e Ministro dell'Interno. Rim: Tip. Elzeviriana, 1885.

Neue Freie Presse (Wien), 1885. Österreichische Nationalbibliothek. ANNO Historische österreichische Zeitungen und Zeitschriften. Pristup ostvaren od 15. do 29. lipnja 2021. https://anno.onb.ac.at/. 
„Od kužne bolnice na 'Zelenom brijegu' do suvremene klinike”. Klinika za infektivne bolesti „Fran Mihaljević”. Pristup ostvaren 3. 6. 2021. https://bfm.hr/ wp-content/uploads/2019/10/Od-kuzne-bolnice-1.pdf.

„Okružnica biskupa Josipa Jurja Strossmayera od 9. svibnja 1863.”; „Okružnica Josipa Jurja Strossmayera, biskupa đakovačkog od 5. lipnja 1863.”; „Druga okružnica o sv. Ćirilu i Metodu biskupa Josipa Jurja Strossmayera (iz 1881. godine)”; „Korizmena poslanica Josipa Jurja Strossmayera - izvadak (4. veljače 1885.)". U: Dokumenti o sv. Ćirilu i Metodu, 59-68, 74-174. Zagreb: Kršćanska sadašnjost, 1985.

Pollitzer, Robert; Swaroop, Satya; Burrows, William. Cholera. World Health Organisation Monograph Series, No. 43. Ženeva, Palais des Nations: George Williams Hooper Foundation, University of California, San Francisco, USA (Formerly of the Division of Communicable Disease Services); World Health Organisation, 1959.

Priante, Monica; Slišković, Slavko. Tondini i Strossmayer. Jedinstveni za jedinstvo. Zagreb: Kršćanska sadašnjost, 2016.

„Prijedlog PREPORUKE VIJEĆA o koordiniranom pristupu ograničavanju slobodnog kretanja kao odgovor na pandemiju bolesti COVID-19, Bruxelles, 4. 9. 2020." EUR-Lex - Pristup zakonodavstvu Europske unije. Pristup ostvaren 2. 2. 2021. https://eur-lex.europa.eu/LexUriServ/LexUriServ.do?uri=COM:2020:0499:FIN:HR:PDF.

Roksandić Vidlička, Sunčana; Galiot, Vinko. „Eksperimenti nad ljudima kao zločin protiv čovječnosti: od nürnberškog medicinskog suđenja do predmeta Pfizer". Godišnjak Akademije pravnih znanosti Hrvatske 7 (2016), br. 1: 186-253.

Sirotković, Hodimir. „Život i djelo đakovačkog biskupa Josipa Jurja Strossmayera". U: Međunarodni znanstveni skup Josip Juraj Strossmayer, Zagreb 19. svibnja 2005. - Đakovo 20. svibnja 2005.: povodom 190. obljetnice rođenja i 100. obljetnice smrti. Zbornik radova, uredio Franjo Šanjek, 25-34. Zagreb: Hrvatska akademija znanosti i umjetnosti, 2006.

Squicciarini, Donato. Nunzi Apostolici a Vienna. Città del Vaticano: Libreria Editrice Vaticana, 1998.

Statistische Übersichten über die Bevölkerung und den Viehstand von Österreich nach der Zählung vom 31. October 1857. Beč: Aus der kaiserlich-königlichen Hof- und Staatsdruckerei, 1859. Pristup ostvaren 27. 5. 2021. https:/archive.org/ details/statistischebers00aust/mode/2up.

Szabo, Agneza. „Juraj Posilović 1894. - 1914.” U: Zagrebački biskupi i nadbiskupi, uredio Franko Mirošević, 481-486. Zagreb: Školska knjiga, 1995.

Šenoa, Zdenko. „Aleksandar Bresztyenszky”. U: Hrvatski biografski leksikon, svezak 2, 297. Zagreb: Leksikografski zavod „Miroslav Krleža”, 1989. 
Šišić, Ferdo, prir. Korespondencija Rački-Strossmayer, knjiga treća: od 5. jan. 1882. do 27. juna 1888. Zagreb: Jugoslavenska akademija znanosti i umjetnosti, 1930.

Šuljak, Andrija. „Biskup Josip Juraj Strossmayer i ćirilometodsko-glagoljska baština”. Diacovensia: teološki prilozi 2 (1994), br. 1: 275-294.

Tolomeo, Rita. Korespondencija Josip Juraj Strossmayer - Cesare Tondini de'Quarenghi. Zagreb: Arhiv Hrvatske, 1984.

„Ustav Republike Hrvatske. Pročišćeni tekst”. Pristup ostvaren 1. 2. 2021. https:// www.zakon.hr/z/94/Ustav-Republike-Hrvatske.

Wiener Allgemeine Zeitung (Wien), 1885. Österreichische Nationalbibliothek. ANNO - Historische österreichische Zeitungen und Zeitschriften. Pristup ostvaren od 15. do 29. lipnja 2021. https://anno.onb.ac.at/.

Żurek, Piotr. „Razlozi ostavke biskupa Josipa Juraja Strossmayera na položaj apostolskog administratora Katoličke crkve u Srbiji”. Časopis za suvremenu povijest 34 (2002), br. 3: 781-804. 


\section{On the Political Aspects of Declaring an Epidemic in the Vicinity of Velehrad in Moravia on the Eve of the Celebration of the Thousandth Anniversary of St Methodius's Death (1885)}

\section{Summary}

The paper investigates the circumstances in which an epidemic was proclaimed in the vicinity of Velehrad in Moravia, on the eve of the celebration of the thousandth anniversary of the St Methodius's death on July 5, 1885, as one of the earliest examples of abusing medicine for political purposes. The events related to the prevention of the Velehrad celebration in 1885 have been analyzed on the basis of correspondence between Bishop Josip Juraj Strossmayer and Franjo Rački, as well as between Lujo and Kosto Vojnović. The analysis focuses on the measure of restricting movement, passed by a consensual decision of the governments of the Austro-Hungarian Monarchy and the Russian Empire, which prevented the organized travel of Slavic pilgrims from other parts of the two empires to Moravia, although the epidemic actually did not occur. The prohibition was purely political in nature, intended to prevent mass religious gatherings of Roman Catholics and Greek Catholics from the Austro-Hungarian Monarchy and the Orthodox and Greek Catholics from the Russian Empire. The aim was to obstruct putting in practice the idea of church unification between the Catholic and Orthodox churches, strongly promoted by the Holy See during the pontificate of Leo XIII (1878-1903). The Austro-Hungarian government considered the idea of church unification as extremely dangerous and an instrument of pan-Slavic propaganda that encouraged the penetration of the Russian Empire into the Balkan and Mediterranean regions, threatening the existence of the Austro-Hungarian Monarchy. The Russian government also considered the idea of church unification to be highly dangerous, especially the affirmation of the Old Church Slavonic liturgy as the common church heritage of Catholic and Orthodox Slavs, which it perceived as an instrument of Catholic proselytism. In addition, in accordance with the position of the Russian Orthodox Church, Russia did not recognize Sts Cyril and Methodius as saints of the Catholic Church, but of the Orthodox Church alone. Affirmation of the Old Church Slavonic liturgy by the Holy See was also directly linked to its efforts to win over the Orthodox Churches in the Balkans for an ecclesiastical union, which Russia considered a potential threat to one of its most important foreign policy priorities, which was expanding its influence to the West. By accepting the ecclesiastical union with the Holy See, the Balkan Orthodox states would be far lesser subject to Russian political influence. Therefore, Russia accepted without hesitation the proposal of the Austro-Hungarian Empire to introduce the measure of prohibiting movement, including closing the border with the Russian Empire, in order to prevent

Zoran Grijak, Croatian Institute of History, Opatička 10, 10000 Zagreb, Croatia, E-mail: zgrijak@ isp.hr 
the pilgrimage to Velehrad. As a support for the hypothesis that the proclamation of the epidemic in the vicinity of Velehrad in 1885 was one of the earliest examples of abusing medicine for political purposes, it is pointed out that no infectious disease was medically registered in Moravia that year by the state institutions of public health. Given the coincidence of the proclamation of the Velehrad epidemic with the fifth cholera pandemic wave in the $19^{\text {th }}$ century (1881-1896), the author draws attention to the discrepancy between the very objective reporting of the Viennese press - the Neue Freie Presse and the Wiener Allgemeine Zeitung - on the Austro-Hungarian anti-epidemic measures in order to prevent the disease from spreading to the territory of the Austro-Hungarian Monarchy, and the very biased and tendentious reporting of the same newspaper on the alleged outbreak in Moravia from mid-June 1885, on the eve of the great Velehrad celebration on July 5,1885 . This is directly related to the fact that the news about the appearance of several infectious diseases in Velehrad and its surroundings were false, and the mentioned press published them under the influence of the Austrian government, which used them for its political agenda. As crucial evidence, which supports the conclusions in this paper about the abuse of medicine for political purposes by the Austro-Hungarian authorities in connection with the Velehrad celebration of 1885, historian Jitka Jonová has mentioned in her paper that the Moravian Health Council, in its statement of July 3, 1885, stated that there was no need to prohibit the pilgrimage to Velehrad for health or epidemiological reasons.

Abuse of medicine by the Austro-Hungarian government in declaring a false epidemic in the vicinity of Velehrad in 1885, as probably one of the earliest examples of such abuse, has been taken as a basis for questioning the justification of all restrictive measures and decisions of public-health and political authorities in cases of serious threats to public health, in cases when they significantly violate the legal and constitutional rights of citizens, especially taking into account some drastic forms of abusing public health measures in the $20^{\text {th }}$ century. The importance of critical attitude adopted by the public towards all important decisions and measures of political and medical authorities has also been emphasized in view of the current Covid-19 pandemic, during which some of the fundamental constitutional rights, including the right to free movement, have been revoked or significantly restricted, similarly to the proclamation of the epidemic in Moravia in 1885. The author indicates that he by no means intends to question the decisions and measures taken to combat the Covid-19 pandemic, or to deny the dangerous effects of the Sars-Cov-2 virus on human health, but only wants to point out that the mentioned decisions and measures, as well as all other public epidemiological measures of a restrictive nature, must be proportionate and continuously subject to critical questioning by the public, and also transparently and consensually explained by the medical authorities, on the basis of whose assessments they are introduced. All this has been emphasized as necessary in order not to jeopardize the trust of citizens in the decisions and measures of public-health and other institutions as well as the political authorities that manage the crisis situations, especially in times of a global pandemic such as the world is currently facing.

Keywords: Velehrad celebration of 1885, Sts Cyril and Methodius, abusing epidemics for political purposes, Austro-Hungarian Monarchy, Russian Empire, Triune Kingdom, Josip Juraj Strossmayer, Lujo Vojnović, Kosto Vojnović, Franjo Rački 